\title{
A Novel Manganese-Rich Pokeweed Biochar for Highly Efficient Adsorption of Heavy Metals from Wastewater: Performance, Mechanisms, and Potential Risk Analysis
}

\author{
Zhe Yang ${ }^{1}$, Wenyong $\mathrm{Hu}^{1}{ }^{1 *}$, Bin Yao ${ }^{2}$, Liangchen Shen ${ }^{1}$, Feifeng Jiang ${ }^{1}$, Yaoyu Zhou ${ }^{2}$ \\ and Avelino Núñez-Delgado ${ }^{3}$ (D) \\ 1 College of Biological Resources and Environmental Science, Jishou University, Jishou 416000, China; \\ 18774990507@163.com (Z.Y.); s1831059477@163.com (L.S.); jiangfeifenghunan@163.com (F.J.) \\ 2 College of Resources and Environment, Hunan Agricultural University, Changsha 410128, China; \\ binyao121@163.com (B.Y.); zhouyy@hunau.edu.cn (Y.Z.) \\ 3 Department of Soil Science and Agricultural Chemistry, Engineering Polytechnic School, \\ Campus University s/n, University Santiago de Compostela, 27002 Lugo, Spain; avelino.nunez@usc.es \\ * Correspondence: huwenyong2@163.com; Tel.: +86-13762157065
}

\section{check for}

updates

Citation: Yang, Z.; Hu, W.; Yao, B.; Shen, L.; Jiang, F.; Zhou, Y.;

Núñez-Delgado, A. A Novel

Manganese-Rich Pokeweed Biochar

for Highly Efficient Adsorption of

Heavy Metals from Wastewater:

Performance, Mechanisms, and

Potential Risk Analysis. Processes

2021, 9, 1209. https://doi.org/

$10.3390 /$ pr9071209

Academic Editor: Francesco Parrino

Received: 12 June 2021

Accepted: 9 July 2021

Published: 14 July 2021

Publisher's Note: MDPI stays neutral with regard to jurisdictional claims in published maps and institutional affiliations.

Copyright: (c) 2021 by the authors. Licensee MDPI, Basel, Switzerland. This article is an open access article distributed under the terms and conditions of the Creative Commons Attribution (CC BY) license (https:// creativecommons.org/licenses/by/ $4.0 /)$.

\begin{abstract}
A novel manganese-rich pokeweed biochar was prepared at different temperatures from manganese-rich pokeweed plants collected at manganese tailings, resulting in materials identified as BC300, BC400, and BC500. The synthetized biochar materials were investigated as regards their potential for removing $\mathrm{Cu}^{2+}, \mathrm{Pb}^{2+}$, and $\mathrm{Cd}^{2+}$, specifically in terms of adsorption performances, adsorption kinetics, adsorption isotherms, and potential environmental pollution risk. The results showed that the sorption process fitted well to the pseudo-second-order kinetic and Langmuir models, and the maximum adsorption capacities of BC500 were 246,326 , and $310 \mathrm{mg} \cdot \mathrm{g}^{-1}$ for $\mathrm{Cu}^{2+}, \mathrm{Pb}^{2+}$, and $\mathrm{Cd}^{2+}$ respectively. The physicochemical characteristics of the biochars, and the adsorption mechanisms, were revealed by using scanning electron microscopy-energy spectrometer, elemental analysis, Brunauer-Emmett-Teller techniques, X-ray diffraction, X-ray photoelectron spectroscopy, and Fourier transform infrared spectroscopy. The sorption mechanism of these three heavy metal ions onto biochars included ion exchange, electrostatic adsorption, chemical adsorption, and precipitation. Besides, the potential pollution risk of manganese-rich pokeweed biochars was significantly reduced after pyrolysis. Therefore, it is feasible to transform manganese-rich pokeweed biomass into manganese-rich pokeweed biochar with potential for heavy metals removal, showing high adsorption capacity, recyclability, and low environmental pollution.
\end{abstract}

Keywords: biochar; heavy metal; adsorption; performance; mechanisms; potential risk analysis

\section{Introduction}

Environmental pollution caused by heavy metals or their compounds is mainly driven by mining and dressing, electroplating, smelting, and a variety of uses of heavy metal products $[1,2]$. Some industrial enterprises discharge, indirectly or directly, untreated heavy metal-contained wastewater into the environment, leading to severe water pollution [3-5]. Manganese is associated with an abundant supply of mineral ores in Hunan Province (China), causing the generation of many Mn tailings wasteland in the long-term mining and smelting process. Due to poor management, some heavy metals (e.g., $\mathrm{Zn}, \mathrm{Cu}, \mathrm{Cd}$, and $\mathrm{Pb}$ ) present in the left lands around the manganese ore area enter the surrounding water (surface water and groundwater), or reach soil, resulting from washing and dissolution by rainwater. These facts suppose high risks of damaging the safety of agriculture and animal husbandry production, as well as for human and environmental health [6,7].

$\mathrm{Cu}, \mathrm{Pb}$, and $\mathrm{Cd}$ are the most common heavy metals presenting toxicity. Once they enter the human body via drinking, eating, breathing or via direct contact, they will deposit and accumulate, with high risks of causing significant damage to the normal function of the 
body [8,9]. And once threshold levels are exceeded, it is easy to cause gene mutations and affect cell inheritance. In some cases, it could produce teratosis or induce cancer [10,11].

At the same time, these heavy metals can penetrate the soil environment under the action of water flow. The roots of plants absorb nutrients from the soil, as well as the heavy metals contained in the ground. The increased levels of heavy metals will affect the growth and development of plants [12].

Overall, it is clear that there is a need for performing an appropriate treatment of wastewater containing heavy metals before being discharged into the environment.

The methods for treating heavy metal in wastewater include flocculation/precipitation, oxidation/reduction, ion exchange, membrane separation, and adsorption. However, some of these methods are not always suitable for removing heavy metals from wastewater due to expensive equipment, high operating costs, and high maintenance costs [13-15].

The adsorption method has attracted the attention of researchers all over the world because of its simple operation, relatively low cost, and high efficiency and selectivity $[16,17]$. When adsorption is used to remove heavy metals from wastewater, its efficiency mainly depends on the choice of the adsorbents, such as biosorbents, polymer fiber, oxide minerals, activated carbon [18,19], and biochar [20,21], which need to have a capacity to effectively adsorb the heavy metals present in wastewater.

Biochar is a relatively novel, low-cost, and carbon-rich porous material, prepared by pyrolysis of biomass in oxygen-deficient environments [22,23]. It is featured with a large specific surface area, strong adsorption capacity, and does caus secondary pollution [24,25]. Biochar has high capacity for the adsorption of heavy metal ions in the environment. The metallic mineral components in biomass (such as calcium, potassium, and other) facilitate the production of biochar and the formation of void structure, thereby enhancing its physical adsorption potential [26]. Especially in recent years, biomass containing heavy metals has been converted into biochar by pyrolysis under anaerobic conditions in an increasing number of research experiments. It is to be noted that the biomass containing heavy metals can be reduced to the maximum extent, effectively reducing the leaching and bioavailability of these heavy metals [27]. Also relevant, the production of toxic and harmful substances (polycyclic aromatic hydrocarbons, dioxins, etc.), as well as greenhouse gases generated in the traditional incineration process, can be effectively avoided. In fact, this is a common method used for the disposal of plant wastes containing heavy metals [28,29].

To achieve a higher adsorption capacity of biochar, different modification methods have been considered. For example, Ying et al. [30] used magnesium (Mg) nutrient solution to cultivate tomato plants for preparing a new type of magnesium-rich biochar. The experimental results showed that the obtained biochar had a $\mathrm{Mg}(\mathrm{OH})_{2}$ and $\mathrm{MgO}$ particlesrich surface, which significantly improved its capacity for adsorption of phosphorus $(\mathrm{P})$ in wastewater. According to Zhou et al. [31], a ferromanganese binary oxide-biochar was prepared by means of an impregnation/sintering method for adsorption of $\mathrm{Cu}^{2+}$ and $\mathrm{Cd}^{2+}$. A manganese salt solution ( $\mathrm{MnCl}_{2}, \mathrm{KMnO}_{4}$, etc.) with potential for modifying biomass could be used to load $\mathrm{MnO}$ particles on the surface of biochar materials through hightemperature pyrolysis. This would help to achieve a significant improvement of biochar composite materials in terms of the number of functional groups, void structure, specific surface area, and adsorption capacity [32,33]. These studies showed that the adsorption capacity of these biochars prepared by modification methods dramatically improved, thereby clearly increasing the efficiency in the removal of heavy metals.

One of the plants with potential for being used in the elaboration of biochar is Phytolacca acinosa, which in fact was used as the raw material to prepare biochar in the current study. It is a perennial stout herbaceous plant with a height of $0.5-1.5 \mathrm{~m}$ and a strong adaptability. Numerous studies have shown that this plant has strong enrichment and tolerance to manganese in soil media [34]. Mn accumulation in its leaves can exceed $19 \mathrm{~g} \cdot \mathrm{kg}^{-1}$, with an average of $14 \mathrm{~g} \cdot \mathrm{kg}^{-1}$. It was the first Mn hyperaccumulator discovered in China [35]. Phytolacca acinosa does not show the biological defects of many hyperaccumulators (small 
size, low biomass, slow growth rate, long growth cycle). It has many advantages such as good adaptability, strong fecundity, and wide geographical distribution. Besides, it should be noted that the specific plant specimens used in this experiment came from a manganese mining area, which is interesting in order to investigate if the overall procedure could aid to solve the problem of treatment and disposal of Phytolacca acinosa containing heavy metals. In addition, converting these plants into biochar could be useful to achieve the adsorption of heavy metals present in wastewater.

In view of that, in this work, manganese-rich pokeweed biomass was used as the raw material for producing novel biochar materials at different temperatures $(300,400$, and $500{ }^{\circ} \mathrm{C}$ ) under anaerobic pyrolysis conditions. Then, the manganese-rich pokeweed biochars were investigated as regards their potential for removing $\mathrm{Cu}^{2+}, \mathrm{Pb}^{2+}$, and $\mathrm{Cd}^{2+}$ from wastewater, this is in terms of adsorption performance, recyclability, and environmental pollution risks. This was carried out performing experiments varying $\mathrm{pH}$, time, temperature, dosage, concentration, and circulation, also focusing on potential risk analysis. Moreover, parameters relevant for kinetics and adsorption isotherms models were also investigated. Finally, the characterization of the biochars before and after adsorption, as well as the adsorption mechanism, were also studied by means of FTIR, SEM-EDS, BET, elemental analysis, and XRD and XPS techniques. The results of the study could be of environmental relevance, especially for recycling of biomass and removal of heavy metals from polluted media.

\section{Materials and Methods}

\subsection{Chemicals and Raw Materials}

The raw materials used for manufacturing biochars in this study were pokeweed plants from the manganese mining area of Xiangxi Prefecture, Hunan province, China. The chemicals used in the experiments, including $\mathrm{NaOH}$ (analytical reagent), $\mathrm{MgCl}_{2}$ (analytical reagent), $\mathrm{CH}_{3} \mathrm{COONH}_{4}$ (analytical reagent), $\mathrm{HONH}_{3} \mathrm{CI}$ (analytical reagent), and $\mathrm{CH}_{3} \mathrm{COOH}$ (analytical reagent) were obtained from Guangdong Xilong Scientific Co. Ltd. (China). $\mathrm{Pb}\left(\mathrm{NO}_{3}\right)_{2}$ (analytical reagent), $\mathrm{Cu}\left(\mathrm{NO}_{3}\right)_{2} \cdot 3 \mathrm{H}_{2} \mathrm{O}$ (analytical reagent) $\mathrm{Cd}\left(\mathrm{NO}_{3}\right)_{2} \cdot 4 \mathrm{H}_{2} \mathrm{O}$ (analytical reagent), $\mathrm{HNO}_{3}$ (analytical reagent), $\mathrm{NaOAc}$ (analytical reagent), and $30 \% \mathrm{H}_{2} \mathrm{O}_{2}$ (analytical reagent) were obtained from Chengdu Jinshan Chemical Reagent Co., Ltd. (China). All the solutions including reagents were prepared with ultrapure water.

\subsection{Preparation of the Biochar}

Peeled manganese-rich pokeweed was used as biomass raw material, which was washed, dried, crushed, and passed through a 100-mesh sieve. A specific amount of sieved biomass was weighed and then placed in a vacuum tube furnace and heated at a rate of $5{ }^{\circ} \mathrm{C} \min ^{-1}$ under $\mathrm{N}_{2}$. Afterwards, it was heated to $300^{\circ} \mathrm{C}, 400{ }^{\circ} \mathrm{C}$, or $500^{\circ} \mathrm{C}$ and kept for $2 \mathrm{~h}$. After being cooled to room temperature, it was washed with ultrapure water and dried to obtain the manganese-rich pokeweed biochar materials (designed as BC300, BC400, and $\mathrm{BC} 500)$. The number (300-500) indicates the pyrolysis temperature during the preparation.

\subsection{Characterization}

The surface morphology changes of the BC300, BC400, and BC500 biochar materials used in this study were observed by means of a Scanning electron microscopy-energy spectrometer (Quanta FEG 250, USA). The specific surface area and pore structure of the BC300, BC400, and BC500 materials were determined by using Brunauer-Emmett-Teller methodology (NOVA4200e, USA). The C, N, H, S, and O elemental contents for the BC300, BC400, and BC500 biochar samples were measured by using an elemental analyzer (EAICE440 , USA). The changes in the surface functional groups of the BC300, BC400, and BC500 materials before and after adsorption were determined by using Fourier transform infrared spectroscopy (Nicolet 5700 Spectrometer, USA). The changes in the crystallinity of the $\mathrm{BC} 300, \mathrm{BC} 400$, and $\mathrm{BC} 500$ biochars before and after the adsorption of the heavy metals were determined by using X-ray diffraction (XRD-6100, Japan). The chemical composition 
of the surfaces of the $\mathrm{BC} 300, \mathrm{BC} 400$, and $\mathrm{BC} 500$ biochars was determined by using X-ray photoelectron spectroscopy (ESCALAB 250Xi, USA).

\subsection{Adsorption Experiments}

We performed every and each adsorption experiment in a constant temperature oscillation incubator at $160 \mathrm{rpm}$, with triplicate samples in each group, where the average values were obtained for analysis and RSD of less than $5 \%$. The concentration of heavy metals before and after adsorption was determined by ICP-OES (Agilent 5800, USA). The calculation formulas of the adsorption capacities and removal rate of biochars towards to heavy metals are as follows:

$$
\begin{aligned}
& Q_{e}=\frac{\left(C_{0}-C_{e}\right) \times V}{M} \\
& R=\frac{C_{0}-C_{e}}{C_{0}} \times 100 \%
\end{aligned}
$$

where $Q_{e}$ is adsorption capacity of biochar $\left(\mathrm{mg} \cdot \mathrm{g}^{-1}\right) ; C_{0}$ and $C_{e}$ are the initial and residual concentration of heavy metal remaining in solution $\left(\mathrm{mg} \cdot \mathrm{L}^{-1}\right)$, respectively; $V$ is the solution volume $(\mathrm{mL}) ; M$ is the mass of biochar $(\mathrm{g})$; and $R(\%)$ is the heavy metal removal rate from solution.

Amounts of $15 \mathrm{mg}$ of BC300, BC400, and BC500, as well as of NM500 and activated carbon, were added to $50 \mathrm{~mL}$ Erlenmeyer flask, and each of them received $50 \mathrm{~mL}$ of $\mathrm{Cu}^{2+}$, $\mathrm{Pb}^{2+}$, or $\mathrm{Cd}^{2+}$ solutions $\left(100 \mathrm{mg} \cdot \mathrm{L}^{-1}\right)$, respectively. Under the same adsorption parameters, we compared the difference in the adsorption capacity among the tested materials.

In the range of $\mathrm{pH} 2-6$, we added $5 \mathrm{mg}$ of $\mathrm{BC} 300, \mathrm{BC} 400$, and $\mathrm{BC} 500$ and $50 \mathrm{~mL}$ of $\mathrm{Cu}^{2+}, \mathrm{Pb}^{2+}$, and $\mathrm{Cd}^{2+}$ solutions $\left(100 \mathrm{mg} \cdot \mathrm{L}^{-1}\right)$ to a $50 \mathrm{~mL}$ Erlenmeyer flask. Then, a small amount of $\mathrm{NaOH}$ or $\mathrm{HNO}_{3}\left(0.1 \mathrm{~mol} \cdot \mathrm{L}^{-1}\right)$ was dropped to adjust the $\mathrm{pH}$.

In addition, we added $5 \mathrm{mg}$ of $\mathrm{BC} 300, \mathrm{BC} 400$, and $\mathrm{BC} 500$ and $50 \mathrm{~mL}$ of $\mathrm{Cu}^{2+}, \mathrm{Pb}^{2+}$, and $\mathrm{Cd}^{2+}$ solutions $\left(100 \mathrm{mg} \cdot \mathrm{L}^{-1}\right)$ to a $50 \mathrm{~mL}$ Erlenmeyer flask, and oscillated at the optimal $\mathrm{pH}$. Then we took aliquots at the corresponding reaction time $(0.25,0.5,1,2,3,6,8,10$, $12,18,24$, and $36 \mathrm{~h})$. To analyze the adsorption mechanism of $\mathrm{Cu}^{2+}, \mathrm{Pb}^{2+}$, and $\mathrm{Cd}^{2+}$ on biochars, we used the pseudo-first-order (PFO) and the pseudo-second-order (PSO) kinetic models. The model formulas are as follows:

$$
\begin{gathered}
q_{t}=q_{e}\left(1-e^{-k_{1} t}\right) \\
q_{t}=\frac{k_{2} q_{e}^{2} t}{1+k_{2} q_{e} t}
\end{gathered}
$$

where $q_{e}$ and $q_{t}$ are the adsorption capacities $\left(\mathrm{mg} \cdot \mathrm{g}^{-1}\right)$ of biochars at equilibrium and at time $t$, respectively, and $k_{1}\left(\mathrm{~min}^{-1}\right)$ and $k_{2}\left(\mathrm{~g} \mathrm{mg}^{-1} \cdot \mathrm{min}^{-1}\right)$ are the rate constants at PFO and $\mathrm{PSO}$, respectively.

At the optimal $\mathrm{pH}$ and reaction time, we added $5 \mathrm{mg}$ of BC300, BC400, and BC500, and $50 \mathrm{~mL}$ of $\mathrm{Cu}^{2+}, \mathrm{Pb}^{2+}$, and $\mathrm{Cd}^{2+}$ solutions $\left(100 \mathrm{mg} \cdot \mathrm{L}^{-1}\right)$ to a $50 \mathrm{~mL}$ Erlenmeyer flask, and oscillated at different temperatures $\left(15,20,25,30\right.$, and $\left.35^{\circ} \mathrm{C}\right)$.

Under the optimum $\mathrm{pH}$, reaction time and reaction temperature, we added 5, 10, 15, 20, 25, and $30 \mathrm{mg}$ of $\mathrm{BC} 300, \mathrm{BC} 400$, and $\mathrm{BC} 500$ respectively, and $50 \mathrm{~mL}$ of $\mathrm{Cu}^{2+}, \mathrm{Pb}^{2+}$, and $\mathrm{Cd}^{2+}$ solutions $\left(100 \mathrm{mg} \cdot \mathrm{L}^{-1}\right)$ to a $50 \mathrm{~mL}$ Erlenmeyer flask, and then oscillated.

Under the optimum $\mathrm{pH}$, reaction time, reaction temperature, and dosage, we added $50 \mathrm{~mL}$ of $\mathrm{Cu}^{2+}, \mathrm{Pb}^{2+}$, and $\mathrm{Cd}^{2+}$ solutions with concentrations of $25,50,100,150,200,300$, and $400 \mathrm{mg} \cdot \mathrm{L}^{-1}$ respectively, to a $50 \mathrm{~mL}$ Erlenmeyer flask, and then oscillated. The adsorption mechanism of $\mathrm{Cu}^{2+}, \mathrm{Pb}^{2+}$, and $\mathrm{Cd}^{2+}$ on biochars was analyzed using the Langmuir model and the Freundlich model. The model formulas are as follows:

$$
q_{e}=\frac{K_{L} q_{m} C_{e}}{1+K_{L} C_{e}}
$$




$$
q_{e}=K_{F} C_{e}^{1 / n}
$$

where $q_{e}$ and $C_{e}$ are the adsorption capacity of biochar at equilibrium $\left(\mathrm{mg}^{-\mathrm{g}^{-1}}\right)$ and the solution concentration at equilibrium $\left(\mathrm{mg} \cdot \mathrm{L}^{-1}\right)$, respectively; $q_{m}$ is the biochar maximum adsorption capacity $\left(\mathrm{mg} \cdot \mathrm{g}^{-1}\right) ; K_{L}\left(\mathrm{~L} \cdot \mathrm{mg}^{-1}\right)$ and $K_{F}\left(\left(\mathrm{mg} \cdot \mathrm{g}^{-1}\right)\left(\mathrm{mg} \cdot \mathrm{L}^{-1}\right)^{-\mathrm{n}}\right)$ are the adsorption constants of Langmuir and Freundlich, respectively; and $n$ is an indicator of the adsorption intensity and heterogenicity.

The manganese-rich pokeweed biochars with the best comprehensive performance were taken as the representative material. The study was carried out for four consecutive cycles under the best adsorption parameters. After each cycle, the adsorbent was regenerated by means of $\mathrm{H}_{2} \mathrm{SO}_{4}$ or $\mathrm{NaOH}\left(0.1 \mathrm{~mol} \cdot \mathrm{L}^{-1}\right)$, washed repeatedly with deionized water, and dried for later use.

\subsection{Potential Risk Analysis}

The Tessier chemical sequence extraction method was used to analyze the presence of heavy metals in manganese-rich pokeweed biomass and manganese-rich pokeweed biochar [36,37]. And the content of $\mathrm{Mn}, \mathrm{Cu}, \mathrm{Zn}$, and $\mathrm{Pb}$ in the sample was determined by ICP-OES analysis. Finally, we employed the Hakanson heavy metal risk assessment index in evaluating the potential pollution risk of the heavy metals in the manganese-rich pokeweed biomass and manganese-rich pokeweed biochars. The formula is as follows:

$$
R I=\sum E_{r}=T_{r} \times C_{f}=T_{f} \times C_{i} \div C_{n}
$$

$R I$ is the potential ecological risk index; $E_{r}$ represents the potential ecological index of a single heavy metal; $C_{f}$ represents the pollution factor; and $C_{i}$ and $C_{n}$ are the transferable part and the stable part of the distribution of the heavy metals, respectively.

\section{Results}

\subsection{Characterization of the Materials \\ 3.1.1. FTIR Analyses}

Figure 1 shows the functional groups on the surface of the manganese-rich pokeweed biochars, in terms of the type and number, which were analyzed by means of FTIR. The adsorption peaks near $3418 \mathrm{~cm}^{-1}$ and $2925 \mathrm{~cm}^{-1}$ were $-\mathrm{OH}$ stretching vibration peaks, indicating the presence of water molecules and hydroxyl groups on the surface of the biochars. The adsorption peaks near $1618 \mathrm{~cm}^{-1}$ to $1594 \mathrm{~cm}^{-1}$ and $1430 \mathrm{~cm}^{-1}$ were due to the vibration of $\mathrm{C}=\mathrm{O}$, indicating that there might be carbonyl groups on the surface of the biochars. The adsorption peaks ranging from $879 \mathrm{~cm}^{-1}$ to $779 \mathrm{~cm}^{-1}$ might be caused by $\mathrm{C}-\mathrm{H}$ bending. The adsorption peak near $517 \mathrm{~cm}^{-1}$ indicated the adsorption peak of the $\mathrm{Mn}-\mathrm{O}$ bond bending vibration in $\mathrm{MnOx}$, which proved the existence of $\mathrm{Mn}$ in the material. According to the analysis of the infrared spectroscopy, we found that the increase in the pyrolysis temperature caused some characteristic peaks of the biochars to shift or disappear, and it should be noted that the presence of abundant surface functional groups can improve the capacity of the manganese-rich pokeweed biochars as regards adsorption of the heavy metal ions [38].

\subsubsection{SEM-EDS Analyses}

As shown in Figure 2, SEM-EDS was used to analyze the surface topography and basic composition of the BC300, BC400, and BC500 biochar materials. From the SEM images, it can be observed that the BC300, BC400, and BC500 biochars had a fibrous structure, uneven pores, and particles on the surface before adsorption [39]. However, the particulate matter may be MnOx. After the adsorption of $\mathrm{Pb}^{2+}$ and $\mathrm{Cd}^{2+}$, the $\mathrm{BC} 500$ biochar showed that the surface particulate matter increased significantly in number, possibly due to compound precipitation of $\mathrm{Pb}^{2+}$ and $\mathrm{Cd}^{2+}$. The signal peak of $\mathrm{Mn}$ could be observed from the EDS spectrum, which also proved the existence of Mn on the surface of the raw materials. The quantitative presence of $\mathrm{Mn}$ in the BC300, BC400, and BC500 materials 
before adsorption was $7.26 \%, 6.91 \%$ and $7.61 \%$, respectively, as noted previously [40]. After the adsorption, $\mathrm{Cu}^{2+}, \mathrm{Pb}^{2+}$, and $\mathrm{Cd}^{2+}$ signal peaks were observed in the corresponding EDS spectra, indicating successful adsorption of the heavy metals onto the BC500 biochar.

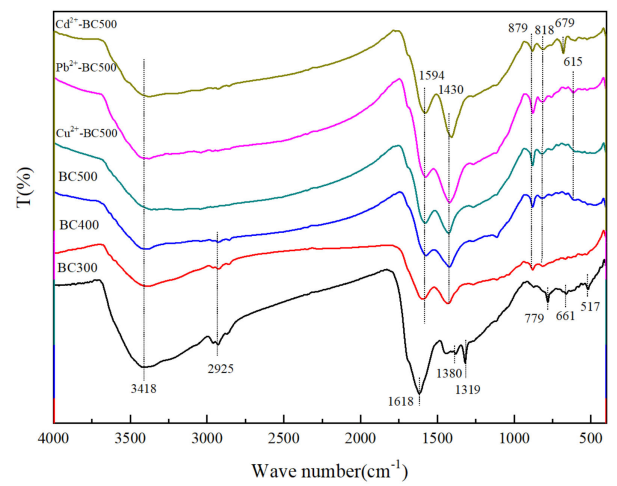

Figure 1. FTIR spectra of the manganese-rich pokeweed biochars here studied.
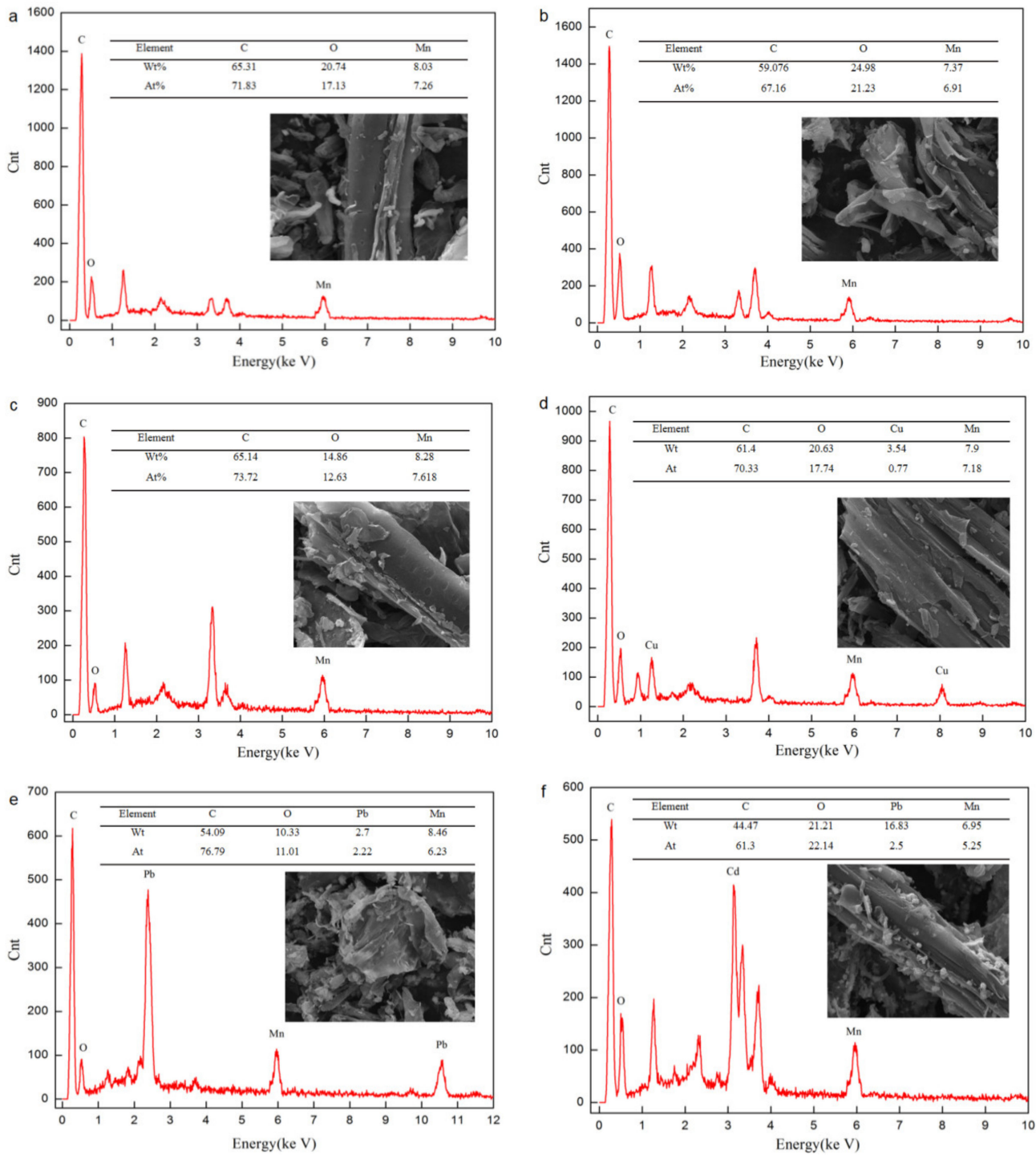

Figure 2. SEM images and EDS spectra of manganese-rich pokeweed biochars: (a) BC300, (b) BC400, (c) BC500, and (d) BC500 after $\mathrm{Cu}^{2+}$ adsorption; (e) BC500 after $\mathrm{Pb}^{2+}$ adsorption; and (f) BC500 after $\mathrm{Cd}^{2+}$ adsorption. 


\subsubsection{BET Results and Elemental Analyses}

Table 1 shows data on pore structure parameters and specific surface area for the $\mathrm{BC} 300, \mathrm{BC} 400$, and BC500 biochars. Comparing some parameters, it was found that since the pyrolysis temperature rose, the surface area and pore size of the biochars increased to different degrees, indicating a certain impact of the pyrolysis temperature in promoting the surface area and pore size of the biochars. However, the fact that the surface of the BC300, BC400, and BC500 materials was loaded with a certain amount of Mn might cause a reduction in the surface area and pore size values.

Table 1. BET parameters of the manganese-rich pokeweed biochars.

\begin{tabular}{ccc}
\hline Sample & Surface Area $\left(\mathbf{m}^{\mathbf{2}} \cdot \mathbf{g}^{-\mathbf{1}}\right)$ & Pore Volume $\left(\mathbf{m}^{\mathbf{3}} \cdot \mathbf{g}^{-\mathbf{1}}\right)$ \\
\hline BC300 & 5.564 & 0.013 \\
BC400 & 9.416 & 0.011 \\
BC500 & 20.233 & 0.014 \\
\hline
\end{tabular}

The element composition of the BC300, BC400, and BC500 materials is shown in Table 2, indicating that as the pyrolysis temperature rose, the content of the $\mathrm{C}$ element continued to increase, while the content of the $\mathrm{N}, \mathrm{H}$, and $\mathrm{O}$ elements decreased, to different degrees. Besides, the $\mathrm{H} / \mathrm{C}$ ratio of the $\mathrm{BC} 300, \mathrm{BC} 400$, and $\mathrm{BC} 500$ materials constantly diminished, which indicates that the increase in the pyrolysis temperature could promote the carbonization of the biochars and contribute to a higher aromaticity. At the same time, the $\mathrm{O} / \mathrm{C}$ ratio of all three materials also gradually decreased, which indicates that the polarity of the biochars gradually decreased with the increase in the pyrolysis temperature. By comparing the elemental compositions among BC300, BC400, and BC500, it was found that $\mathrm{BC} 500$ had a higher content of the $\mathrm{C}$ element and aromaticity, but with the lowest polarity, which was more conducive to the adsorption of the heavy metals [41].

Table 2. Elemental composition of the manganese-rich pokeweed biochars.

\begin{tabular}{ccccccc}
\hline Sample & $\mathbf{C} \%$ & $\mathbf{N} \%$ & $\mathbf{H} \%$ & $\mathbf{O} \%$ & $\mathbf{H} / \mathbf{C}$ & O/C \\
\hline BC300 & 61.6 & 0.93 & 4.62 & 28.724 & 0.075 & 0.46 \\
BC400 & 65.83 & 0.83 & 3.87 & 24.442 & 0.058 & 0.37 \\
BC500 & 69.49 & 0.51 & 3.5 & 21.91 & 0.05 & 0.31 \\
\hline
\end{tabular}

\subsubsection{XRD Analyses}

Figure 3 shows the XRD patterns of the BC300, BC400, and BC500 biochars, as well as of the $\mathrm{BC} 500$ biochar after the adsorption of $\mathrm{Cu}^{2+}, \mathrm{Pb}^{2+}$, and $\mathrm{Cd}^{2+}$. Such patterns showed that $\mathrm{BC} 300, \mathrm{BC} 400$, and $\mathrm{BC} 500$ all had strong diffraction peaks at $2 \theta=30.067$, which corresponded to the typical diffraction peaks of $\mathrm{MnO}_{2}$ [40]. As the pyrolysis temperature went up, the diffraction peaks of $\mathrm{MnO}_{2}$ increased, to different degrees, indicating a major effect of the pyrolysis temperature on this specific peak $[42,43]$. After the BC500 adsorbed $\mathrm{Cu}^{2+}$, $\mathrm{Pb}^{2+}$, and $\mathrm{Cd}^{2+}$, the diffraction peaks of $\mathrm{MnO}_{2}$ showed different degrees of weakening, with no new peaks appearing after the adsorption of $\mathrm{Cu}^{2+}$, while new diffraction peaks corresponding to $\mathrm{Pb}_{3}\left(\mathrm{CO}_{3}\right)_{2}(\mathrm{OH})_{2}, \mathrm{PbCO}_{3}$, and $\mathrm{CdCO}_{3}$ were detected after the adsorption of $\mathrm{Pb}^{2+}$ and $\mathrm{Cd}^{2+}$, respectively. This indicates that precipitation is a consistent as sorption mechanism for $\mathrm{Pb}^{2+}$ and $\mathrm{Cd}^{2+}$ retention onto $\mathrm{BC} 500$, which is coherent with the fine particles appearing in the SEM image after the adsorption of these last two metals $[38,43]$.

\subsubsection{XPS Analyses}

Figure 4 shows the XPS patterns of the BC300, BC400, and BC500 biochars before and after the adsorption of $\mathrm{Cu}^{2+}, \mathrm{Pb}^{2+}$, and $\mathrm{Cd}^{2+}$. As presented in Figure $4 \mathrm{a}$, the carbon and oxygen functional groups changed on the biochar surface before and after adsorption in terms of the binding energy, which indicates the importance of these functional groups 
in the process of adsorption of the heavy metals [44]. After $\mathrm{Cu}^{2+}, \mathrm{Pd}^{2+}$ and $\mathrm{Cd}^{2+}$ were adsorbed onto $\mathrm{BC} 500$, and peaks corresponding to $\mathrm{Cu} 2 \mathrm{p} 3, \mathrm{~Pb} 4 \mathrm{f}$, and $\mathrm{Cd} 3 \mathrm{~d}$ were detected, indicating that the biochars had successfully adsorbed the heavy metals. As shown in Figure $4 \mathrm{~b}, \mathrm{C}$ 1s spectrum, the three peaks corresponding to BC $300, \mathrm{BC} 400$, and BC500 at binding energies of $284.8,286.3$, and $288.2 \mathrm{ev}$ were $\mathrm{C}=\mathrm{C}, \mathrm{C}-\mathrm{O}$, and $\mathrm{C}=\mathrm{O}$. However, there were almost no changes in the peak positions, which is similar to other materials in previous works [45]. By comparing the $\mathrm{BC} 500$ spectra after adsorption, we found that the peak areas of $\mathrm{C}=\mathrm{C}, \mathrm{C}-\mathrm{O}$, and $\mathrm{C}=\mathrm{O}$ changed significantly, which indicates the reaction of the functional groups with heavy metals on the surface of the biochars [31,46]. As shown in Figure 4c, Mn2p spectrum, the binding energies of BC300, BC400, and BC500 at $654.18 \mathrm{ev}$ and $642.33 \mathrm{ev}$ corresponded to the characteristic peaks of Mn2p3/2 and Mn2p1/2 in $\mathrm{MnO}_{2}$, respectively. The binding energy $645.13 \mathrm{ev}$ corresponded to the characteristic peaks of $\mathrm{Mn} 2 \mathrm{p} 3 / 2$ in $\mathrm{MnO}$ or $\mathrm{Mn}_{2} \mathrm{O}_{3}$, which indicates that $\mathrm{Mn}$ was mainly $\mathrm{MnO}_{2}$ in the manganese-rich pokeweed biochars [47].

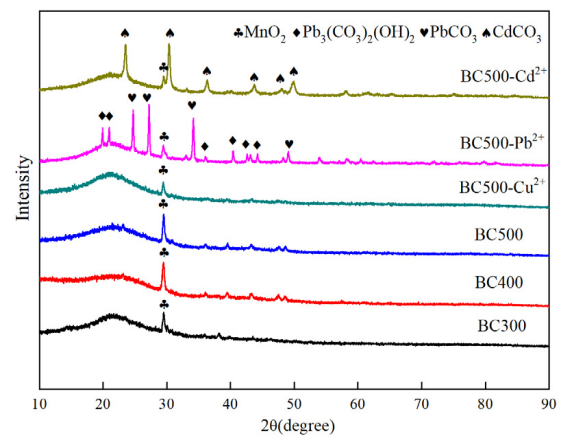

Figure 3. XRD diagrams of the manganese-rich pokeweed biochars.
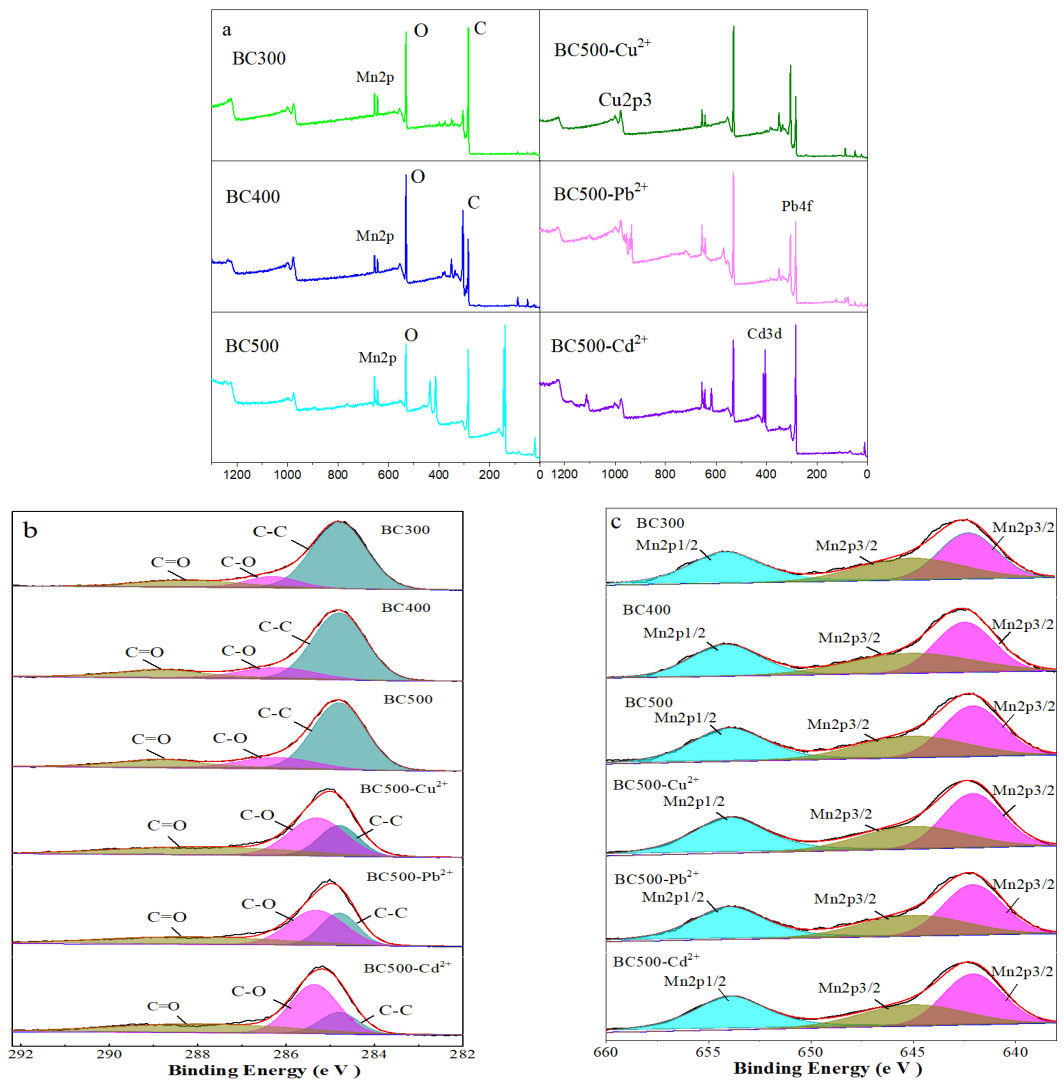

Figure 4. XPS diagrams of manganese-rich pokeweed biochars: (a) XPS survey spectra, (b) C 1s spectra, (c) Mn2p spectra. 


\subsection{Adsorption Experiments}

\subsubsection{The Effect of $\mathrm{pH}$}

Biochars are significantly affected by the solution $\mathrm{pH}$ in terms of the adsorption capacity [48]. As shown in Figure 5a-c, when the $\mathrm{pH}$ increased from 2 to 6, adsorption capacity and removing rate for $\mathrm{Cu}^{2+}$ rapidly increased, and then slightly decreased, onto $\mathrm{BC} 300$, $\mathrm{BC} 400$, and $\mathrm{BC} 500$. It is important to note that the adsorption capacity and removing rate of $\mathrm{Pb}^{2+}$ and $\mathrm{Cd}^{2+}$ were positively correlated. When the solution was at a low $\mathrm{pH}$, the surfaces of the biochars were positively charged, which would cause the electrostatic repulsion of the heavy metal ions, thereby reducing the adsorption capacity of the biochars $[48,49]$. However, with the rise of $\mathrm{pH}$, the biochars were less protonated, thereby increasing their negative charge on the surfaces and promoting its capacity for adsorption of the heavy metals [50,51]. When the $\mathrm{Cu}^{2+}$ and $\mathrm{Pb}^{2+}$ solutions had a $\mathrm{pH}=6$, and the $\mathrm{Cd}^{2+}$ solution had a $\mathrm{pH}=7$, precipitation occured in the solution. Therefore, the adsorption of the heavy metal was affected. Subsequently, the $\mathrm{Cu}^{2+}$ and $\mathrm{Pb}^{2+}$ solutions had a $\mathrm{pH}=5$, and the $\mathrm{Cd}^{2+}$ solution had a $\mathrm{pH}=6$. Under the optimal $\mathrm{pH}$ conditions, the adsorption capacity of $\mathrm{BC} 500$ was $246.21,328$, and $284 \mathrm{mg} \mathrm{g}^{-1}$ for $\mathrm{Cu}^{2+}, \mathrm{Pb}^{2+}$ and $\mathrm{Cd}^{2+}$, respectively, visibly higher than the maximum adsorption capacities of $\mathrm{BC} 300$ and $\mathrm{BC} 400$. This might be due to the fact that specific surface area and pore size of the carbon surface were related to functional groups [52].
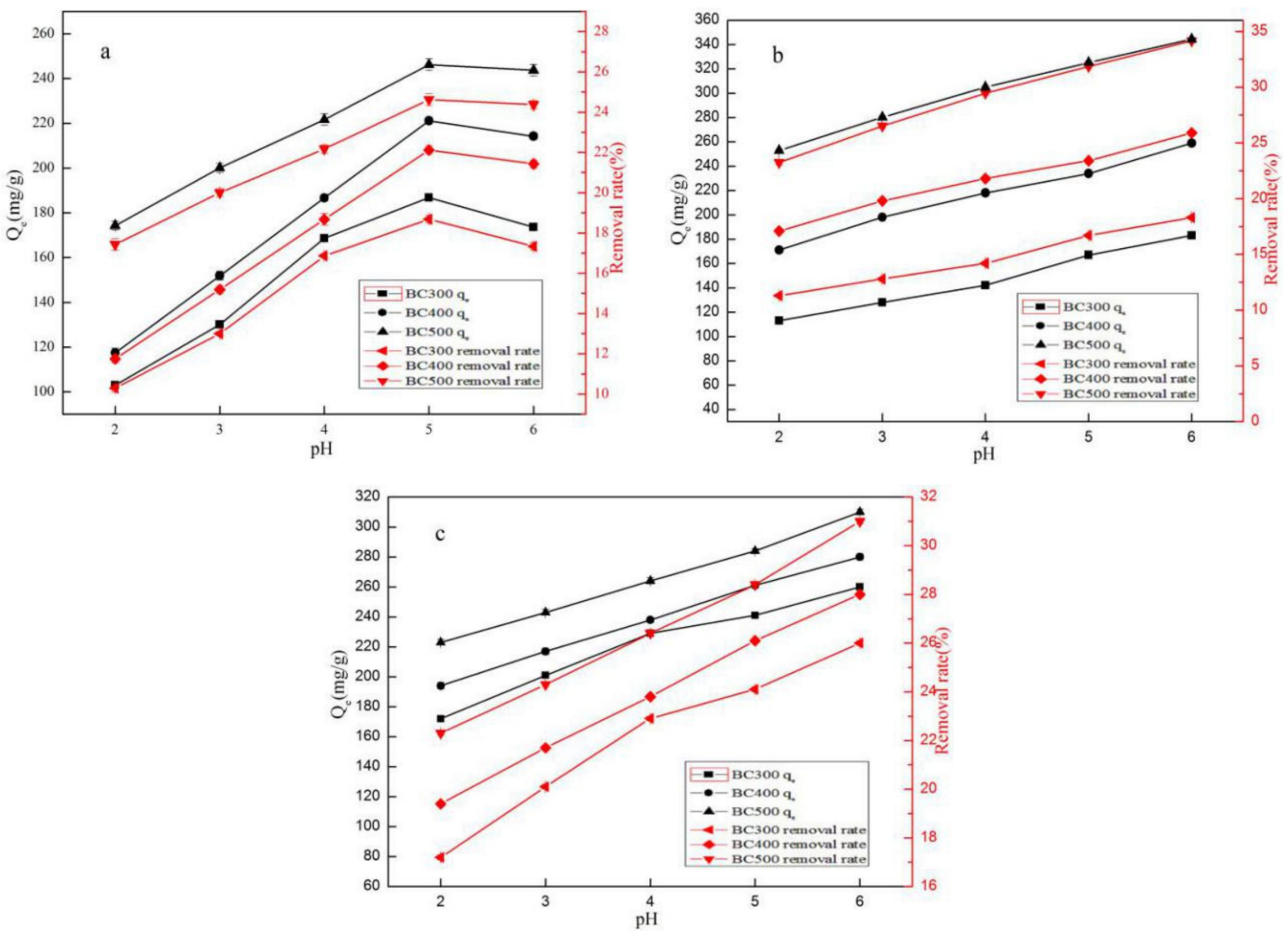

Figure 5. The effect of solution $\mathrm{pH}$ on the adsorption of three different heavy metals by the manganese-rich pokeweed biochars: (a) $\mathrm{Cu}^{2+},(\mathbf{b}) \mathrm{Pb}^{2+},(\mathbf{c}) \mathrm{Cd}^{2+}$.

\subsubsection{Adsorption Kinetics}

As shown in Figure $6 \mathrm{a}-\mathrm{c}$, the reaction time had an effect on the adsorption behavior of BC300, BC400, and BC500. The adsorption process included two main stages. In the initial stage, the adsorption capacity increased rapidly, due to the biochars having many 
adsorption sites on their surfaces [53]. Subsequently, a decelerated adsorption rate was seen until reaching the adsorption equilibrium $[54,55]$.
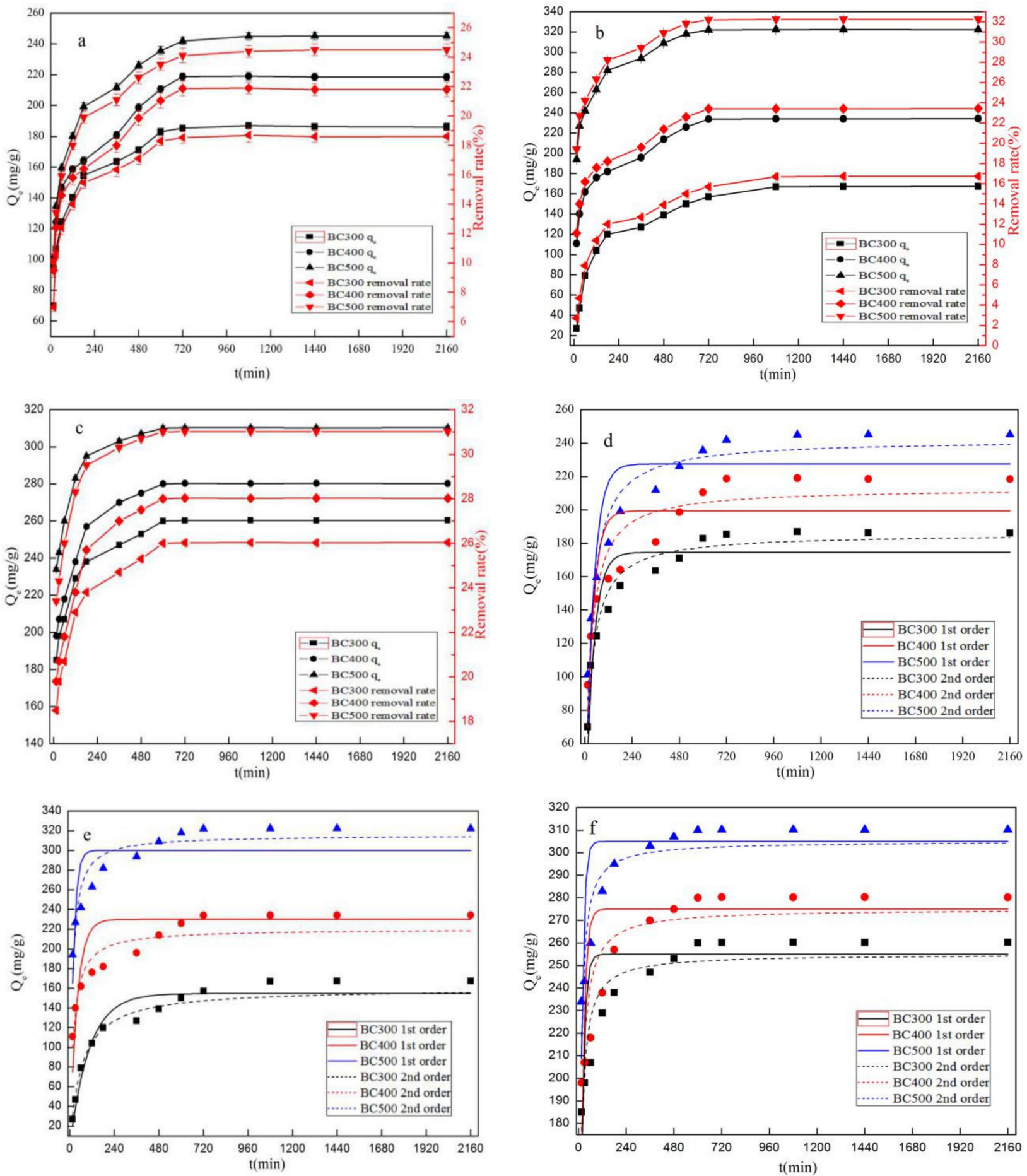

Figure 6. Data regarding adsorption kinetics for the manganese-rich pokeweed biochars: (a) $\mathrm{Cu}^{2+},(\mathbf{b}) \mathrm{Pb}^{2+},(\mathbf{c}) \mathrm{Cd}^{2+}$. Data on fitting to kinetic models: (d) $\mathrm{Cu}^{2+},(\mathbf{e}) \mathrm{Pb}^{2+},(\mathbf{f}) \mathrm{Cd}^{2+}$.

To study the mechanism of adsorption of the $\mathrm{Cu}^{2+}, \mathrm{Pb}^{2+}$, and $\mathrm{Cd}^{2+}$ by the $\mathrm{BC} 300$, BC400, and BC500 biochars, the experimental data were fitted to the PFO and PSO models, with the fitting results shown in Figure $6 \mathrm{~d}-\mathrm{f}$ and Table 3 , in line with what was done in previous works [56]. $\mathrm{R}^{2}$ values were higher for the PSO model than for the PFO model, and the simulated adsorption capacity in the PSO model was also relatively close to the 
experimental data. This indicates that the adsorption of $\mathrm{Cu}^{2+}, \mathrm{Pb}^{2+}$, and $\mathrm{Cd}^{2+}$ by the $\mathrm{BC} 300$, BC400, and BC500 biochars was more in line with the PSO model and that the adsorption process was mainly chemisorption $[57,58]$.

Table 3. The adsorption kinetic parameters for $\mathrm{Cu}^{2+}, \mathrm{Pb}^{2+}$, and $\mathrm{Cd}^{2+}$.

\begin{tabular}{ccccccc}
\hline \multirow{2}{*}{ Adsorbent } & \multicolumn{3}{c}{ PFO } & \multicolumn{3}{c}{ PSO } \\
& $Q_{e}\left(\mathbf{m g} \cdot \mathbf{g}^{-\mathbf{1}}\right)$ & $\boldsymbol{k}_{\mathbf{1}}$ & $\boldsymbol{R}^{\mathbf{2}}$ & $\boldsymbol{Q}_{\boldsymbol{e}} \mathbf{( m g \cdot \mathbf { g } ^ { - 1 } \mathbf { ) }}$ & $\boldsymbol{k}_{\mathbf{2}}$ & $\boldsymbol{R}^{\mathbf{2}}$ \\
\hline $\mathrm{BC} 300-\mathrm{Cu}^{2+}$ & 174.52597 & 0.02544 & 0.83879 & 185.55783 & 1.97835 & 0.96389 \\
$\mathrm{BC} 400-\mathrm{Cu}^{2+}$ & 199.43948 & 0.02895 & 0.69816 & 212.80717 & 1.87106 & 0.88866 \\
$\mathrm{BC} 500-\mathrm{Cu}^{2+}$ & 227.52499 & 0.02527 & 0.79485 & 242.06866 & 1.51741 & 0.94866 \\
$\mathrm{BC} 300-\mathrm{Pb}^{2+}$ & 154.68393 & 0.00964 & 0.93444 & 160.15713 & 9.96497 & 0.96666 \\
$\mathrm{BC} 400-\mathrm{Pb}^{2+}$ & 190.51352 & 0.02642 & 0.60892 & 229.21786 & 2.50427 & 0.87913 \\
$\mathrm{BC} 500-\mathrm{Pb}^{2+}$ & 280.64762 & 0.05335 & 0.66377 & 315.52997 & 2.60974 & 0.88855 \\
$\mathrm{BC} 300-\mathrm{Cd}^{2+}$ & 214.25541 & 0.06576 & 0.59985 & 252.24123 & 5.1848 & 0.86809 \\
$\mathrm{BC} 400-\mathrm{Cd}^{2+}$ & 229.54123 & 0.06143 & 0.55518 & 275.27413 & 4.36213 & 0.83837 \\
$\mathrm{BC} 500-\mathrm{Cd}^{2+}$ & 242.57136 & 0.07693 & 0.53173 & 306.54189 & 5.54803 & 0.88314 \\
\hline
\end{tabular}

\subsubsection{The Effect of Temperature}

As shown in Figure $7 \mathrm{a}-\mathrm{c}$, the reaction temperatures had an effect on the adsorption properties of the $\mathrm{BC} 300, \mathrm{BC} 400$, and $\mathrm{BC} 500$ materials. The adsorption capacities and removing rates of $\mathrm{BC} 300, \mathrm{BC} 400$, and $\mathrm{BC} 500$ for $\mathrm{Cu}^{2+}, \mathrm{Pb}^{2+}$, and $\mathrm{Cd}^{2+}$ increased when the temperature rose from $15^{\circ} \mathrm{C}$. As the temperature continued to increase from $25^{\circ} \mathrm{C}$, they began to gradually decrease. Therefore, the best temperature for adsorption was $25^{\circ} \mathrm{C}$.
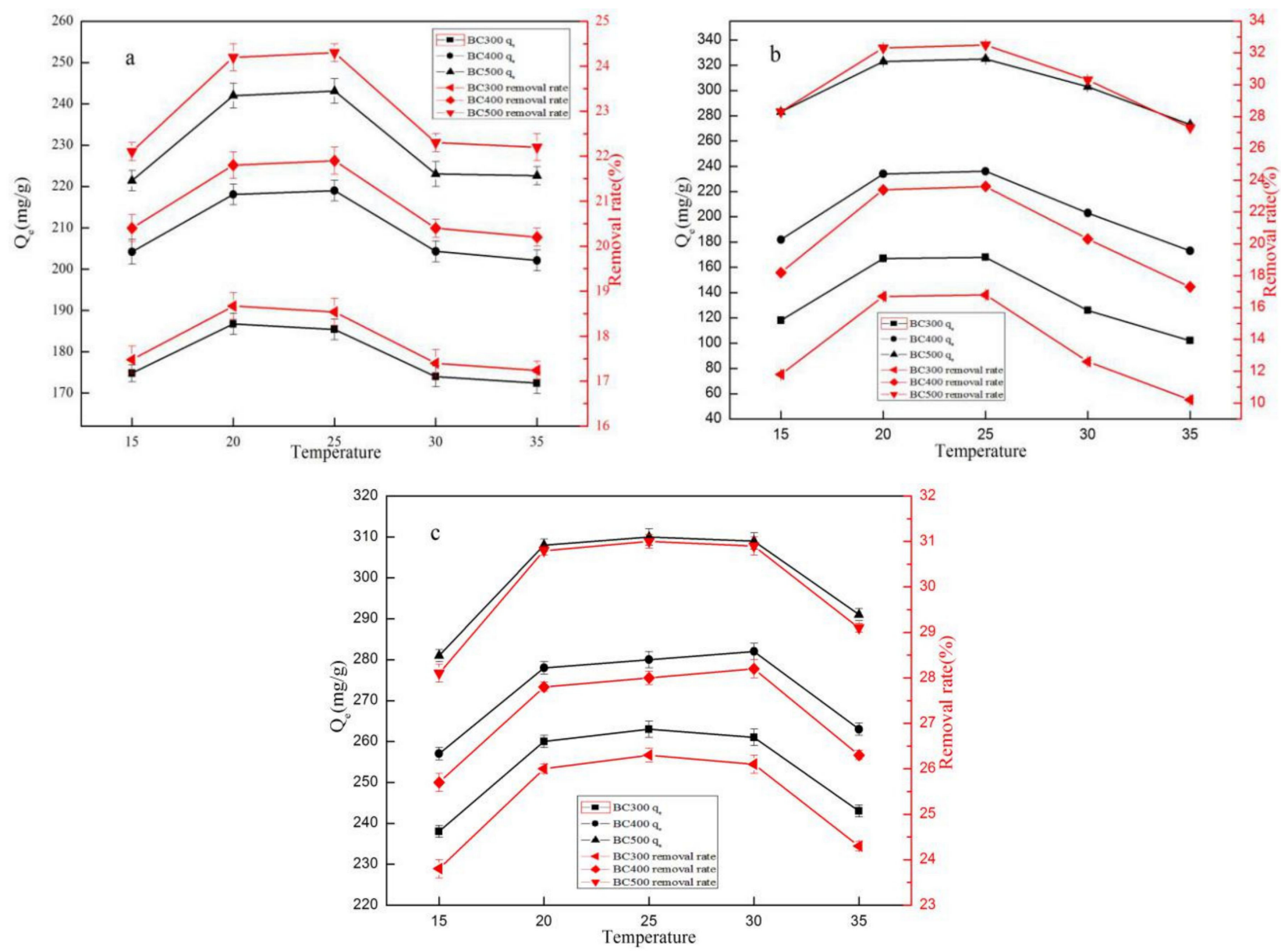

Figure 7. The effect of reaction temperature on the adsorption of heavy metals by the manganese-rich pokeweed biochars: (a) $\mathrm{Cu}^{2+},(\mathbf{b}) \mathrm{Pb}^{2+}$, (c) $\mathrm{Cd}^{2+}$. 


\subsubsection{The Effect of Dosages}

As shown in Figure 8a-c, the dosages also had an effect on the adsorption behavior of $\mathrm{BC} 300, \mathrm{BC} 400$, and $\mathrm{BC} 500$. With the increase in the dosage, the rate of removal of $\mathrm{Cu}^{2+}$, $\mathrm{Pb}^{2+}$, and $\mathrm{Cd}^{2+}$ by BC300, BC400, and BC500 showed a rapid increase until it stabilized; however, the adsorption capacity was stable in the early stage, but rapidly decreased in the later stage. The removal rate rose with the rise in dosage, which provided more adsorption sites and surface area [59]. The decrease in the adsorption capacity was due to the progressive saturation of the adsorption sites caused by the adsorption reaction [60]. Especially, when the dosage of the $\mathrm{BC} 500$ was $15 \mathrm{mg}$, the rate to remove $\mathrm{Cu}^{2+}$ was as high as $98.5 \%$; and when the dosage was $20 \mathrm{mg}$, the rate to remove $\mathrm{Pb}^{2+}$ and $\mathrm{Cd}^{2+}$ reached $97.5 \%$ and $92.7 \%$, respectively.
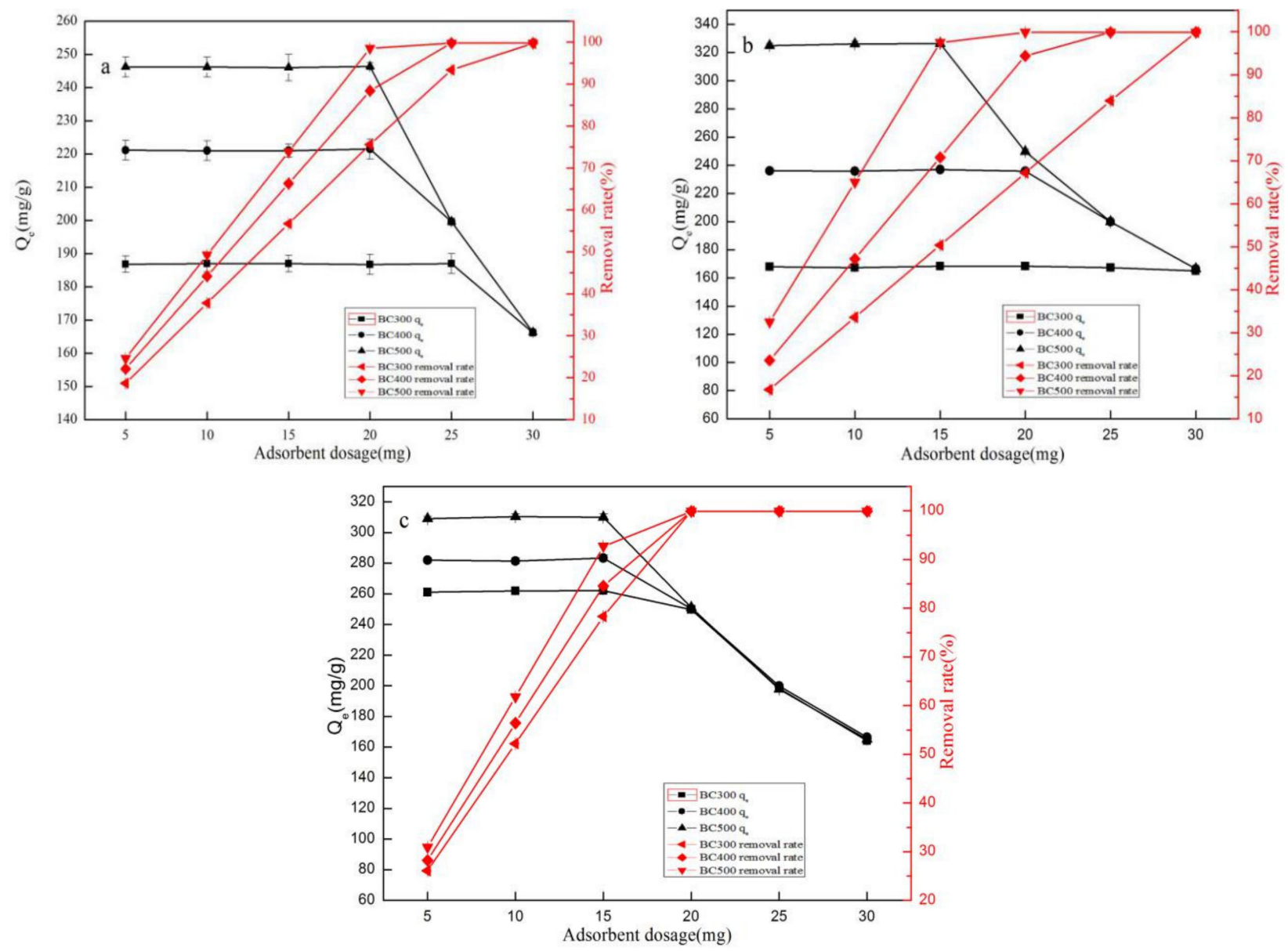

Figure 8. The effect of dosage on the adsorption of heavy metals by the manganese-rich pokeweed biochars: $(\mathbf{a}) \mathrm{Cu}^{2+}$, (b) $\mathrm{Pb}^{2+},(\mathbf{c}) \mathrm{Cd}^{2+}$.

\subsubsection{Adsorption Isotherms}

As shown in Figure $9 \mathrm{a}-\mathrm{c}$, the initial concentration affected the adsorption properties of $\mathrm{BC} 300, \mathrm{BC} 400$, and BC500. At low $\mathrm{Cu}^{2+}, \mathrm{Pb}^{2+}$, and $\mathrm{Cd}^{2+}$ concentrations (below $100 \mathrm{mg} \cdot \mathrm{L}^{-1}$ ), the adsorption capacities and removal rates of BC300, BC400, and BC500 increased as a function of the concentration added. At these low concentrations of the heavy metals, a lot of adsorption sites remained available on the surfaces of the biochars [61]. With the increase in the concentration of heavy metals added, the adsorption capacity of BC300, $\mathrm{BC} 400$, and BC500 gradually approached saturation, and the removal rate began to decline rapidly. However, by increasing the dosage of the biochars, the removal rate could be increased even for high concentrations of heavy metals [62-64]. 

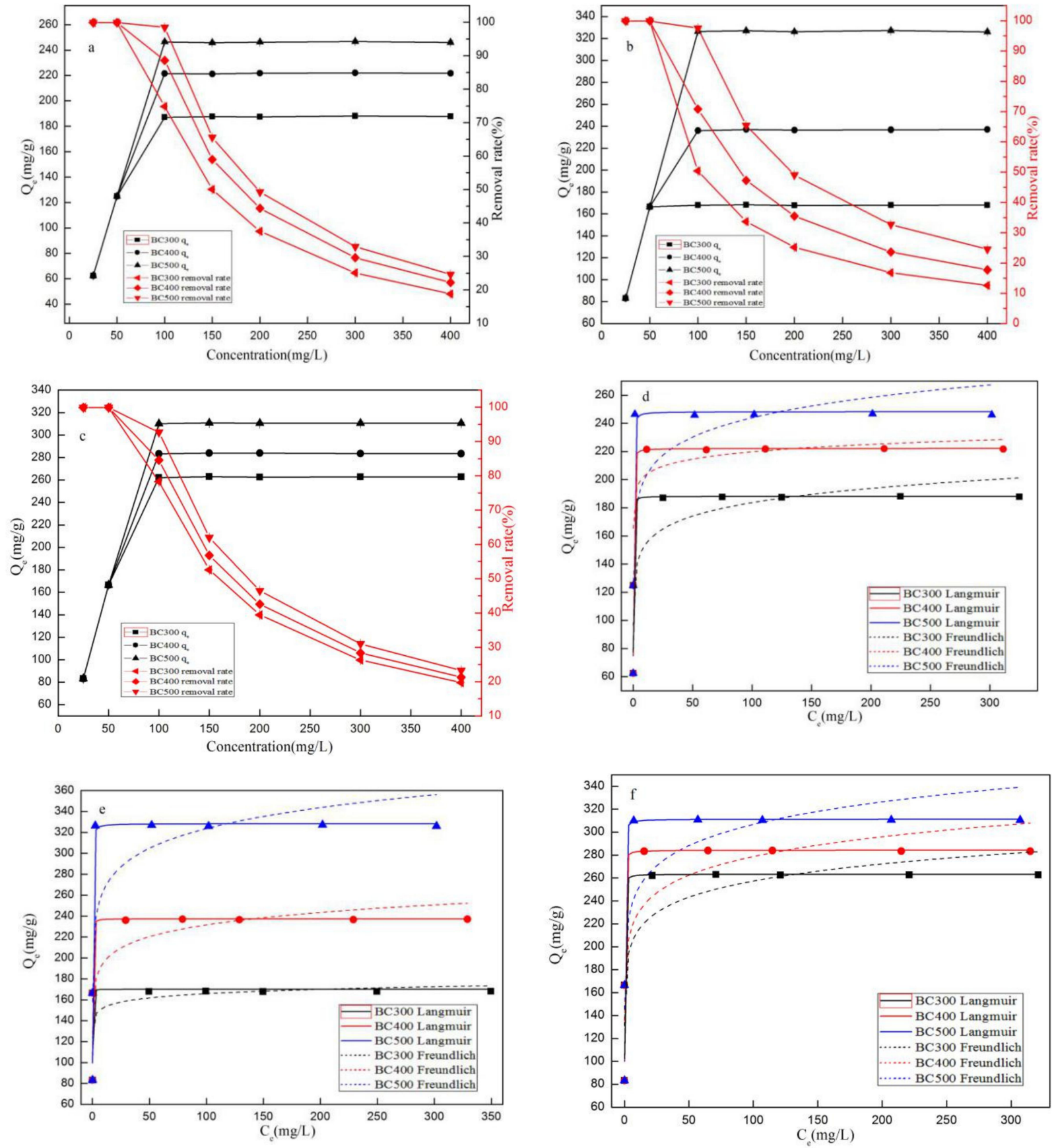

Figure 9. Effect on adsorption due to the initial concentration of the heavy metals added: (a) $\mathrm{Cu}^{2+},(\mathbf{b}) \mathrm{Pb}^{2+}, \mathrm{and}(\mathbf{c}) \mathrm{Cd}^{2+}$. Adsorption curves for the manganese-rich pokeweed biochars: (d) $\mathrm{Cu}^{2+}$ adsorption isotherm, (e) $\mathrm{Pb}^{2+}$ adsorption isotherm, and (f) $\mathrm{Cd}^{2+}$ adsorption isotherm.

In addition, the Langmuir model and the Freundlich model were used to further study adsorption. Figure $9 \mathrm{~d}-\mathrm{f}$ and Table 4 show that, according to the observations, the capacities of the manganese-rich pokeweed biochars for the adsorption of the heavy metals followed the sequence $\mathrm{BC} 500>\mathrm{BC} 400>\mathrm{BC} 300$, while their rates of removal were $\mathrm{Pb}^{2+}>\mathrm{Cd}^{2+} \mathrm{Cu}^{2+}>\mathrm{Cu}^{2+}$. PB500 showed maximum adsorption capacities of 246,326 , and $310 \mathrm{mg} \cdot \mathrm{g}^{-1}$ for $\mathrm{Cu}^{2+}, \mathrm{Pb}^{2+}$, and $\mathrm{Cd}^{2+}$, respectively. It is important to note that the $\mathrm{R}^{2}$ values of the Langmuir model were higher than those of the Frendlich model. This indicated that the adsorption of the heavy metals $\mathrm{Cu}^{2+}, \mathrm{Pb}^{2+}$, and $\mathrm{Cd}^{2+}$ by the BC300, $\mathrm{BC} 400$, and BC500 biochars was more consistent with the Langmuir model, meaning that the adsorption process was dominated by monolayer interactions [65]. 
Table 4. The adsorption isotherms parameters of $\mathrm{Cu}^{2+}, \mathrm{Pb}^{2+}$, and $\mathrm{Cd}^{2+}$.

\begin{tabular}{ccccccc}
\hline \multirow{2}{*}{ Adsorbent } & \multicolumn{3}{c}{ Langmuir } & \multicolumn{3}{c}{ Freundlich } \\
& $\boldsymbol{Q}_{\boldsymbol{m}}\left(\mathbf{m g ~ g} \mathbf{~}^{-\mathbf{1}}\right.$ & $\boldsymbol{K}_{\boldsymbol{L}}$ & $\boldsymbol{R}^{\mathbf{2}}$ & $\boldsymbol{K}_{\boldsymbol{F}}$ & $\boldsymbol{n}$ & $\boldsymbol{R}^{\mathbf{2}}$ \\
\hline $\mathrm{BC} 300-\mathrm{Cu}^{2+}$ & 188.18668 & 28.02274 & 0.96239 & 128.6307 & 0.07737 & 0.79598 \\
$\mathrm{BC} 400-\mathrm{Cu}^{2+}$ & 222.20807 & 20.67084 & 0.98487 & 187.66081 & 0.0343 & 0.51224 \\
$\mathrm{BC} 500-\mathrm{Cu}^{2+}$ & 248.30945 & 10.33169 & 0.98888 & 166.26842 & 0.08327 & 0.65712 \\
$\mathrm{BC} 300-\mathrm{Pb}^{2+}$ & 170.12479 & 70.51657 & 0.6445 & 140.66621 & 0.03573 & 0.55412 \\
$\mathrm{BC} 400-\mathrm{Pb}^{2+}$ & 237.54248 & 31.24189 & 0.9487 & 166.11347 & 0.07216 & 0.77502 \\
$\mathrm{BC} 500-\mathrm{Pb}^{2+}$ & 328.39095 & 17.43978 & 0.99035 & 217.32022 & 0.08652 & 0.69727 \\
$\mathrm{BC} 300-\mathrm{Cd}^{2+}$ & 263.34945 & 25.55479 & 0.9713 & 176.87751 & 0.08143 & 0.80421 \\
$\mathrm{BC} 400-\mathrm{Cd}^{2+}$ & 284.33611 & 22.21888 & 0.98114 & 186.82251 & 0.08687 & 0.80392 \\
$\mathrm{BC} 500-\mathrm{Cd}^{2+}$ & 311.37099 & 18.9919 & 0.98834 & 202.64684 & 0.09002 & 0.77071 \\
\hline
\end{tabular}

\subsubsection{Effects of Repeated Adsorption Cycles}

The manganese-rich pokeweed biochar BC500 with the best comprehensive performance was used as representative material. The adsorption study was carried out for four consecutive cycles under the best adsorption conditions. As shown in Figure 10, the capacity of the BC500 in adsorption of the $\mathrm{Cu}^{2+}, \mathrm{Pb}^{2+}$, and $\mathrm{Cd}^{2+}$ decreased, to different degrees, after several cycles. Its capacity in adsorption of the $\mathrm{Cu}^{2+}, \mathrm{Pb}^{2+}$, and $\mathrm{Cd}^{2+}$ decreased from 244,321 , and $307 \mathrm{mg} \cdot \mathrm{g}^{-1}$, to 108,183 , and $228 \mathrm{mg} \cdot \mathrm{g}^{-1}$, respectively. In general, the adsorption capacity of the $\mathrm{BC} 500$ remained at a high level after four cycles, indicating that the material had good recyclability.

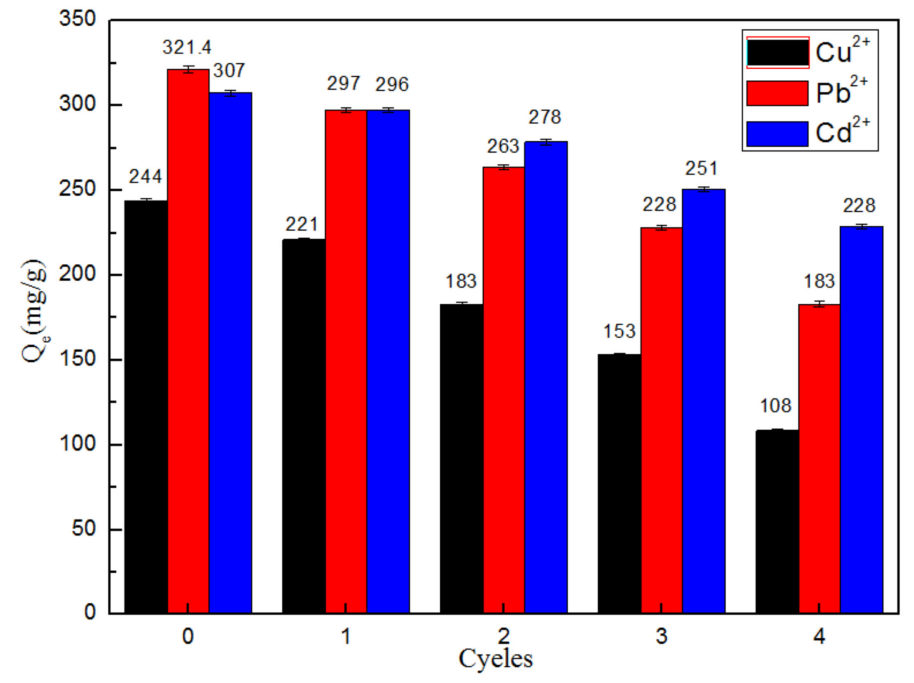

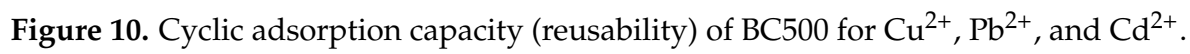

\subsection{Potential Risk Analysis}

The Tessier chemical sequence extraction method was used to study the morphological distribution of the heavy metals $\mathrm{Mn}, \mathrm{Zn}, \mathrm{Cu}$, and $\mathrm{Pb}$ in the manganese-rich pokeweed biomasses $\mathrm{BC} 300, \mathrm{BC} 400$, and $\mathrm{BC} 500$, as indicated in previous works [66]. As shown in Figure 11, the heavy metals in the manganese-rich pokeweed biomasses $\mathrm{BC} 300, \mathrm{BC} 400$, and $\mathrm{BC} 500$ were divided into five forms: exchangeable state, carbonate-bound state, ironmanganese-bound state, organic-bound state, and residue state. The results were as follows: Mn was mainly present in the form of the iron-manganese combined state (65\%) in the manganese-rich pokeweed biomasses. As the transformation pyrolysis temperature increased, the iron-manganese combined state of manganese in the BC500 dropped to $31 \%$, while the residual state rose to $55 \%$. Zn was mainly present in the form of carbonate-bound $(29 \%)$ and iron-manganese $(44 \%)$ in the manganese-rich pokeweed biomasses. With the increase in the pyrolysis temperature, the carbonate-bound state and iron manganese- 
bound state of the $\mathrm{Zn}$ in the $\mathrm{BC} 500$ decreased to $13 \%$ and $27 \%$, respectively, while the residual state rose to $38 \%$. Cu was mainly present in the form of carbonate combined state $(30 \%)$ and iron-manganese combined state $(31 \%)$ in the manganese-rich pokeweed biomasses. With the increase in the pyrolysis temperature, the carbonate binding state and ferromanganese binding state in the $\mathrm{Cu}$ in the BC500 decreased to $12 \%$ and $8 \%$, respectively, while the residue state rose to $55 \%$. Pb was mainly in the form of carbonate-bound (19\%) and iron-manganese $(44 \%)$ in the manganese-rich pokeweed biomasses. With the increase in the pyrolysis temperature, the carbonate-bound state and iron manganese-bound state of the $\mathrm{Pb}$ in the $\mathrm{BC} 500$ decreased to $2 \%$ and $17 \%$, respectively, while the residue state rose to $52 \%$.
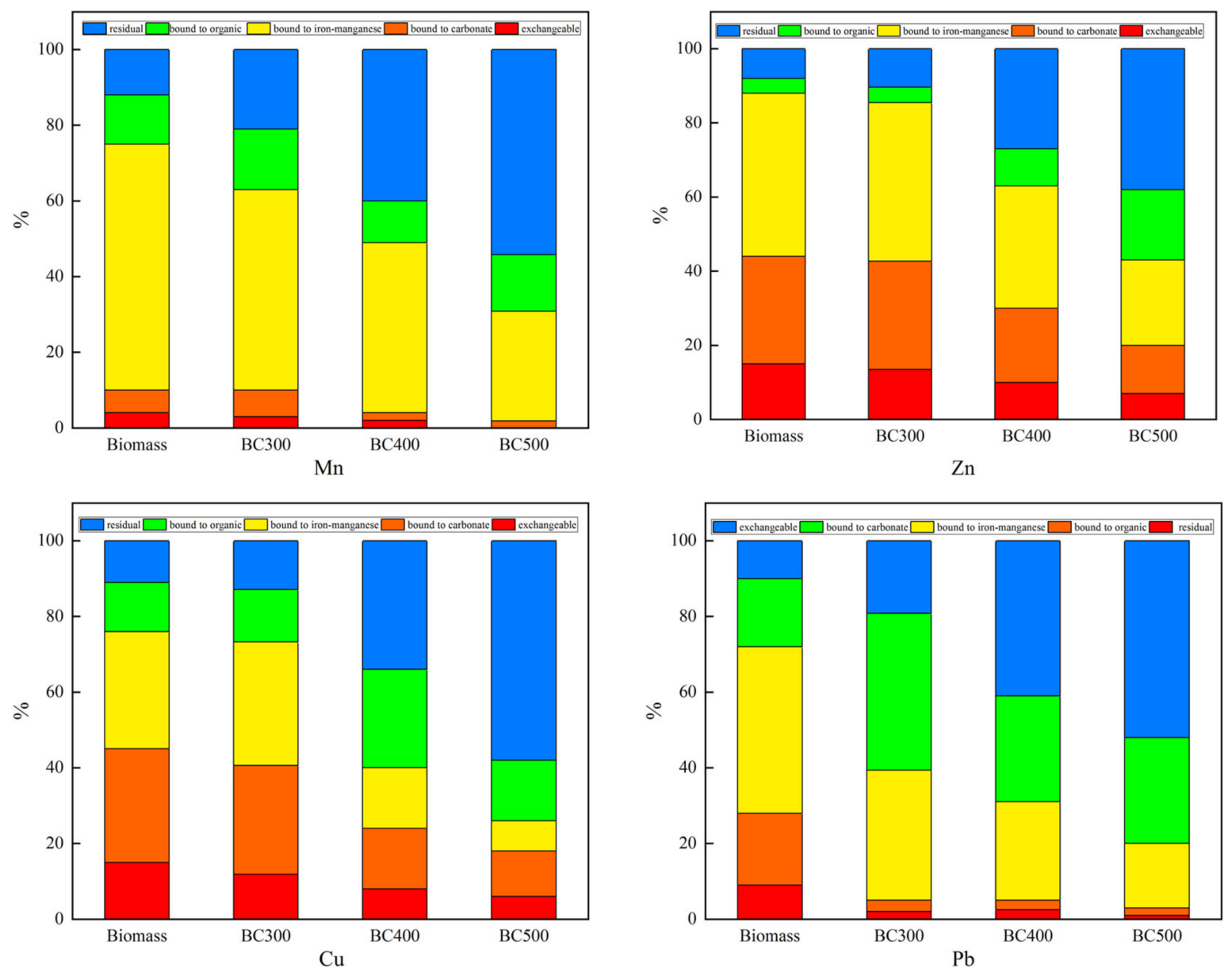

Figure 11. The distribution of heavy metals $\mathrm{Mn}, \mathrm{Zn}, \mathrm{Cu}$, and $\mathrm{Pb}$ in the manganese-rich pokeweed biomass, BC300, BC400, and BC500.

Based on the above analysis, the heavy metals were present in the manganese-rich pokeweed biomasses mainly in the form of higher activity, which would cause a certain potential pollution risk to the environment. However, the pyrolysis could promote the heavy metals to convert from a more active form to a stable residue state. As the pyrolysis temperature increased, the conversion ratio of the residue state increased, as previously shown [67]. The increase in the residue state content indicated high stability of the heavy metals in the material [68].

The Hakanson heavy metal risk assessment index was adopted for evaluating the potential pollution risk of the heavy metals in the manganese-rich pokeweed biomasses BC300, BC400, and BC500 [69]. The specific index classification standards and statistics are shown in Tables 5 and 6, indicating that the $C_{f}$ values of the $\mathrm{Mn}, \mathrm{Zn}, \mathrm{Cu}$, and $\mathrm{Pb}$ in the manganese-rich pokeweed biomasses were $7.33,11.5,8.09$, and 9 , respectively. As the 
pyrolysis temperature rose, the $C_{f}$ of the $\mathrm{Mn}, \mathrm{Zn}, \mathrm{Cu}$ and $\mathrm{Pb}$ continued to decrease, and its risk was also decreasing. In particular, the $\mathrm{C}_{f}$ of $\mathrm{Mn}, \mathrm{Zn}, \mathrm{Cu}$, and $\mathrm{Pb}$ in $\mathrm{BC} 500$ decreased to $0.81,1.89,0.72$, and 0.92 , respectively.

Table 5. Index classification of Hakanson potential risk assessment.

\begin{tabular}{cccc}
\hline $\boldsymbol{E}_{\boldsymbol{r}}$ & Potential Ecological Risk & $\boldsymbol{R I}$ & Biochar Contamination \\
\hline$E_{r}<40$ & Low & $R I \leq 50$ & Low \\
$40 \leq E_{r}<80$ & Moderate & $50<R I \leq 100$ & Moderate \\
$80 \leq E_{r}<160$ & Considerable & $100 \leq R I<200$ & Considerable \\
$160 \leq E_{r}<320$ & High & $R I>200$ & High \\
$E_{r} \geq 320$ & Very high & & \\
\hline
\end{tabular}

Table 6. Potential risk assessment of heavy metals in the manganese-rich pokeweed biomass, BC300, BC400, and BC500.

\begin{tabular}{|c|c|c|c|c|c|}
\hline Samples & Parameter & Mn & $\mathrm{Zn}$ & $\mathrm{Cu}$ & $\mathbf{P b}$ \\
\hline \multirow{3}{*}{ Biomass } & $C_{f}$ & 7.33 & 11.5 & 8.09 & 9 \\
\hline & $E_{r}$ & 7.33 & 11.5 & 40.45 & 45 \\
\hline & $R I$ & \multicolumn{4}{|c|}{104.28} \\
\hline \multirow{3}{*}{ ВС 300} & $C_{f}$ & 3.76 & 9 & 6.69 & 4.26 \\
\hline & $E_{r}$ & 3.76 & 9 & 33.45 & 21.3 \\
\hline & $R I$ & \multicolumn{4}{|c|}{67.51} \\
\hline \multirow{3}{*}{ BC400 } & $C_{f}$ & 1.5 & 2.7 & 1.94 & 1.43 \\
\hline & $E_{r}$ & 1.5 & 2.7 & 9.7 & 7.15 \\
\hline & $R I$ & \multicolumn{4}{|c|}{21.05} \\
\hline \multirow{3}{*}{ BC500 } & $C_{f}$ & 0.81 & 1.89 & 0.72 & 0.92 \\
\hline & $E_{r}$ & 0.81 & 1.89 & 3.6 & 4.6 \\
\hline & $R I$ & \multicolumn{4}{|c|}{10.9} \\
\hline
\end{tabular}

$\mathrm{Cu}$ and $\mathrm{Pb}$ had the main risk factors in the $E_{r}$ of the manganese-rich pokeweed biomasses, with risk coefficients of 40.45 and 45 , respectively, representing moderate potential ecological risk. As the pyrolysis temperature went up, the $E_{r}$ of $\mathrm{Mn}, \mathrm{Zn}, \mathrm{Cu}$, and $\mathrm{Pb}$ continued to decrease, and their potential risks also decreased. In particular, the $E_{r}$ of $\mathrm{Mn}, \mathrm{Zn}, \mathrm{Cu}$, and $\mathrm{Pb}$ in BC500 dropped to 0.81, 1.89, 3.6, and 4.6, respectively, which meant that the potential ecological risk had dropped to a low level.

According to the RI values, it can be seen that the manganese-rich pokeweed biomasses had a considerable potential ecological risk due to the heavy metals, reaching 104.28. However, after the pyrolysis, the potential ecological risks of BC300, BC400, and BC500 were reduced to 67.51, 21.05, and 10.9, respectively. Compared with the biomasses, the potential ecological risk of the heavy metals in the biochars after the pyrolysis was significantly reduced. Especially, for BC500, it was reduced to a low level. It showed that preparing the biomasses into the biochars could effectively reduce the potential pollution risk of the heavy metals.

\section{Conclusions}

In this study, three manganese-rich pokeweed biochar materials (designed as BC300, BC400 and BC500) were prepared from manganese-rich pokeweed plants to study its performance as regards adsorption of $\mathrm{Cu}^{2+}, \mathrm{Pb}^{2+}$, and $\mathrm{Cd}^{2+}$. Under the optimal conditions and values of the adsorption parameters, one of the biochars (BC500) showed maximum adsorption capacity as high as 246,326 , and $310 \mathrm{mg} \cdot \mathrm{g}^{-1}$ for $\mathrm{Cu}^{2+}, \mathrm{Pb}^{2+}$, and $\mathrm{Cd}^{2+}$, meaning $98.5,97.5$, and $92.7 \%$ in removing rates. After being used for four cycles, the adsorption capacity was maintained, and the potential pollution risk of the heavy metals remained low. Regarding adsorption kinetics and adsorption isotherms, the PSO and the Langmuir models fitted well to the experimental data. By means of different characterization analyses 
(FTIR, SEM-EDS, BET, XRD, and XPS), it was shown that the Mn in the biochars was mainly $\mathrm{MnO}_{2}$, with these sorbent materials having many functional groups on their surfaces. The mechanism involved in the sorption of $\mathrm{Cu}^{2+}, \mathrm{Pb}^{2+}$, and $\mathrm{Cd}^{2+}$ onto the three biochars $(\mathrm{BC} 300$, $\mathrm{BC} 400$ and $\mathrm{BC} 500)$ included ion exchange, electrostatic attraction, chemical adsorption, and precipitation. All three biochars (BC300, BC400, and BC500) were featured with high adsorption capacity, recyclability, and low environmental pollution. The elaboration of these biochar materials could be also used for scientific treatment and disposal of the manganese-rich pokeweed plants. Overall, the results of the study can be considered of clear environmental relevance.

Author Contributions: Conceptualization, Z.Y., W.H., Y.Z., A.N.-D.; methodology, Z.Y., W.H.; software, L.S., F.J.; writing-original draft, Z.Y., B.Y.; writing-review and editing, W.H., Y.Z., A.N.-D.; supervision, W.H., A.N.-D. All authors have read and agreed to the published version of the manuscript.

Funding: The study was financially supported by the Natural Science Foundation of Hunan Province, China (Grant No. 2018JJ3242), China Postdoctoral Science Foundation (Grant No. 2018M630901).

Conflicts of Interest: All co-authors have no conflicts of interest.

\section{References}

1. Chen, Y.; Jiang, X.; Wang, Y.; Zhuang, D. Spatical characteristics of heavy metal pollution and the potential ecological risk of a typical mining area: A case study in China. Process Saf. Environ. 2018, 113, 204-219. [CrossRef]

2. Kranthi, K.; Sardar, R.; Bhargavi, E.; Devi, I.; Bhunia, B.; Tiwari, N. Advances in exopolysaccharides based bioremediation of heavy metals in soil and water: A critical review. Carbohydr. Polym. 2018, 199, 353-364.

3. Fu, L.; Wang, Q. Removal of heavy metal ions from wastewaters: A review. J. Environ. Manag. 2011, 92, 407-418. [CrossRef]

4. Li, N.; Kang, Y.; Pan, W.; Zeng, L.; Zhang, Q.; Luo, J. Concentration and transportation of heavy metals in vegetables and risk assessment of human exposure to bioaccessible heavy metals in soil near a waste incinerator site. Sci. Total Environ. 2015, 521, 144-151. [CrossRef] [PubMed]

5. Kumar, R.; Rani, M.; Gupta, H.; Gupta, B. Trace metal fractionation in water and sediments of an urban river stretch. Chem. Speciat. Bioavailab. 2014, 26, 200-209. [CrossRef]

6. Yu, F.; Liu, K.; Ye, P.; Zhou, Z.; Chen, S.; Li, Y. Manganese tolerance and accumulation characteristics of a woody accumulator Camellia oleifera. Environ. Sci. Pollut. Res. 2019, 26, 21329-21339. [CrossRef]

7. Moreno, L.; Neretnieks, I. Long-term environmental impact of tailings deposits. Hydrometallurgy 2006, 83, 176-183. [CrossRef]

8. Chavan, A.; Li, H.; Scarpellini, A.; Marras, S.; Manna, L.B.; Athanassiou, A.; Fragouli, D. Elastomeric nanocomposite foams for the removal of heavy metal ions from water. ACS Appl. Mater. Interfaces 2015, 7, 14778-14784. [CrossRef]

9. Gollavelli, G.; Chang, C.; Ling, C. Facile synthesis of smart magnetic graphene for safe frinking water: Heavy matal removal and disinfection control. ACS Sustain. Chem. Eng. 2013, 1, 462-472. [CrossRef]

10. Song, W.; Liu, M.; Hu, R. Water-soluble polyacrylamide coated-Fe $\mathrm{O}_{4}$ magnetic composites for high-effcient enrichment of U(IV) from radioactive wastewater. Chem. Eng. J. 2014, 246, 268-276. [CrossRef]

11. Vukovic, D.; Marinkovic, D.; Colic, M.; Ristic, D.; Aleksic, R.; Grujic, P.; Uskokovic, S. Removal of cadmium from aqueous solutions solutions by oxidized and ethylenedi amine-functionalized multi-walled carbon nanotubes. Chem. Eng. J. 2010, 157, 238-248. [CrossRef]

12. Li, Z.; Ma, Z.; Van, J. A review of soil heavy metal pollution from mines in China: Pollution and health risk assessment. Sci. Total Environ. 2014, 2, 843-853. [CrossRef] [PubMed]

13. Zhao, T.; Ma, S.; Zheng, Y.; Han, W.; Yao, X.; Wang, Z.; Wang, S.; Feng, K. $\beta$-cyclodextrin functionalized biochars as novel sorbents for high-performance of $\mathrm{Pb}^{2+}$ removal. J. Hazard. Mater. 2019, 362, 206-216. [CrossRef] [PubMed]

14. Ni, J.; Huang, S.; Wang, C.; Ni, Y.; Sun, J.; Wei, W. Competitive adsorption of heavy metals in aqueous solution onto biochar derived from anaerobically digested sludge. Chemosphere 2019, 219, 351-357. [CrossRef]

15. Mahmoud, E.; Khalifa, A.; Wakeel, M.; Header, S.; Sharkawy, M.; Kumar, S.; Fattah, M. A novel nanocomposite of Liquidambar styraciflua fruit biochar-crosslinked-nanosilica for uranyl removal from water. Bioresour. Technol. 2019, 278, 124-129. [CrossRef]

16. Guilhen, N.; Masek, O.; Ortiz, N.; Izidoro, C.; Fungaro, A. Pyrolytic temperature evaluation of macauba biochar for uranium adsorption from aqueous solutions. Biomass Bioenergy 2019, 122, 381-390. [CrossRef]

17. Jiang, H.; Li, Y.; Deng, H.; Ye, H.; Wu, Q.; Lin, D.; Hang, L. Characteristics of nitrogen and phosphorus adsorption by Mg-loaded biochar from different feedstocks. Bioresour. Technol. 2019, 276, 183-189. [CrossRef]

18. Kermit, W.; Hong, Y.; Chuang, W.S.; Wayne, E.M. Select metal adsorption by activated carbon made from peanut shells. Bioresour. Technol. 2006, 97, 2260-2270.

19. Rao, M.; Ramana, K.; Seshaiah, K.; Wang, C.; Chien, C. Removal of some metal ions by activated carbon prepared from phaseolus aureus hulls. J. Hazard. Mater. 2009, 166, 1006-1013. [CrossRef] 
20. Leng, J.; Huang, J.; Li, H.; Zhou, G. Biochar stability assessment methods: A review. Bioresour. Technol. 2019, 647, $210-220$. [CrossRef]

21. Xu, J.; Cao, Z.; Zhang, Y.; Yuan, Z.L.; Lou, Z.; Xu, X.H.; Wang, X.K. A review of functionalized carbon nanotubes and graphene for heavy metal adsorption from water: Preparation, application, and mechanism. Chemosphere 2018, 195, 351-364. [CrossRef] [PubMed]

22. Dinesh, M.; Ankur, S.; Yong, O.; Charles, P. Organic and inorganic contaminants removal from water with biochar, a renewable, low cost and sustainable adsorbent-A critical review. Bioresour. Technol. 2014, 160, 191-202.

23. Ahmad, M.; Rajapaksha, A.U.; Lim, E.; Zhang, M.; Bolan, N.; Mohan, D. Biochar as a sorbent for contaminant management in soil and water: A review. Chemosphere 2014, 99, 19-33. [CrossRef]

24. Yu, W.; Lian, F.; Cui, G.; Liu, Z. N-doping effectively enhances the adsorption capacity of biochar for heavy metal ions from aqueous solution. Chemosphere 2018, 193, 8-16. [CrossRef] [PubMed]

25. Chen, C.; Chen, G.; Chen, G.; Chen, G. Adsorption of copper and zinc by biochars produced from pyrolysis of hardwood and corn straw in aqueous solution. Bioresour. Technol. 2011, 102, 8877-8884. [CrossRef]

26. Xiao, F.; Cheng, J.; Cao, W.; Yang, C.; Chen, J.; Lou, Z. Removal of heavy metals from aqueous solution using chitosan-combined magnetic biochars. J. Colloid Interface Sci. 2019, 540, 579-584. [CrossRef]

27. Dilks, R.; Monette, F.; Glaus, M. The major parameters on biomass pyrolysis for hyperaccumulative plants: A review. Chemosphere 2016, 146, 385-395. [CrossRef]

28. Fletcher, J.; Smith, A.; Heinemeyer, A.; Lord, R.; Ennis, J.; Hodgson, M.; Farrar, K. Production factors controlling the Physical Characteristics of biochar Derived from phytoremediation Willow for agricultural Applications. Bioenergy Res. 2013, 7, 371-380. [CrossRef]

29. Chami, A.; Amer, N.; Smets, K.; Yperman, J.; Carleer, R.; Dumontet, S.; Vangronsveld, J. Evaluation of flash and slow pyrolysis applied on heavy metal contaminated Sorghum bicolor shoots resulting from phytoremediation. Biomass Bioenergy 2014, 63, 268-279. [CrossRef]

30. Ying, Y.; Bin, G.; Jian, J.C.; Ming, Z.; Man, D.; Yu, C.L.; Liu, Y.Y. Engineered carbon (biochar) prepared by direct pyrolysis of Mg-accumulated tomato tissues: Characterization and phosphate removal potential. Bioresour. Technol. 2013, 138, 8-13.

31. Zhou, Q.; Liao, B.; Lin, L.; Qiu, W.W.L.; Song, Z.G. Adsorption of Cu(II) and Cd(II) from aqueous solutions by ferromanganese binary oxide-biochar composites. Sci. Total Environ. 2018, 615, 115-122. [CrossRef]

32. Liu, B.; Tan, F.; Liu, G. Production of biochars from Ca impregnated ramie biomass (Boehmeria nivea (L.) Gaud.) and their phosphate removal potential. RSC Adv. 2016, 6, 5871-5880. [CrossRef]

33. Zhou, L.; Liu, Y.G.; Liu, S.B.; Yin, Y.C.; Zeng, G.M.; Tan, X.F.; Hu, X.; Hu, X.J.; Jiang, L.H.; Ding, Y.; et al. Investigation of the adsorption-reduction mechanisms of hexavalent chromium by ramie biochars of different pyrolytic temperatures. Bioresour. Technol. 2016, 218, 351-359. [CrossRef]

34. Liu, G.; Zhang, Z.; Zeng, M.; Huang, B.; Li, X. Heavy metal accumulation in plants on Mn mine tailings. Pedosphere 2006, 16, 131-136. [CrossRef]

35. Xue, G.; Chen, X.; Reeves, D.; Baker, M.; Lin, Q.; Fernando, R. Manganese uptake and accumulation by the hyperaccumulator plant Phytolacca acinosa Roxb. (Phytolaccaeae). Environ. Pollut. 2004, 131, 393-399. [CrossRef]

36. Jin, C.; Nan, Z.R.; Wang, H.C.; Jin, P. Plant growth and heavy metal bioavailability changes in a loess subsoil amended with municipal sludge compost. J. Soils Sediments 2017, 17, 2797-2809. [CrossRef]

37. Tessier, A.; Campbell, P.G.C.; Bisson, M. Sequential extraction procedure for the speciation of particulate trace metals. Anal. Chem. 1979, 51, 844-851. [CrossRef]

38. Chen, S.; Tong, C.; Qun, H.; Jun, W.; Sheng, L.; Jian, Y. Enhanced adsorption for $\mathrm{Pb}(\mathrm{II})$ and $\mathrm{Cd}(\mathrm{II})$ of magnetic rice husk biochar by $\mathrm{KMnO}_{4}$ modification. Environ. Sci. Pollut. R. 2019, 26, 8902-8913.

39. Chen, H.; Wang, Y.Y.; Wei, Y.X.; Peng, L.; Li, G.; Yu, G.L.; Du, C.Y. Wet flue gas desulfurization wastewater treatment with reclaimed water treatment plant sludge: A case study. Water Sci. Technol. 2018, 78, 2392-2403. [CrossRef] [PubMed]

40. Guang, T.; Yu, W.; Yong, L.; Dan, X. Removal of $\mathrm{Pb}$ (II) ions from aqueous solution by manganese oxide coated rice straw biochar-A low-cost and highly effective sorbent. J. Taiwan Inst. Chem. Eng. 2018, 7, 177-191.

41. Mishra, S.; Dwivedi, J.; Kumar, A.; Sankararamakrishnan, N. Removal of antimonite (Sb(iii)) and antimonate (Sb(v)) using zerovalent iron decorated functionalized carbon nanotubes. RSC Adv. 2016, 6, 95865-95878. [CrossRef]

42. Chang, L.; Lei, Z.; Yuan, G.; Aimin, L. Facile synthesis of nano ZnO/ZnS modified biochar by directly pyrolyzing of zinc contaminated corn stover for $\mathrm{Pb}(\mathrm{II}), \mathrm{Cu}(\mathrm{II})$ and $\mathrm{Cr}(\mathrm{VI})$ removals. Waste Manag. 2018, 79, 625-637.

43. Jian, C.; Hai, Z.; Hong, C.; Yang, Y.; Ming, C.; Yan, C.; Fei, H.; Guo, Z.; Meng, Y. Spent Ganoderma lucidum substrate derived biochar as a new bio-adsorbent for $\mathrm{Pb}^{2+} / \mathrm{Cd}^{2+}$ removal in water. Chemosphere 2019. [CrossRef]

44. Wang, H.; Gao, B.; Wang, S.; Fang, J.; Xue, Y.; Kai, Y. Removal of Pb(II), Cu(II), and Cd(II) from aqueous solutions by biochar derived from $\mathrm{KMnO}_{4}$ treated hickory wood. Bioresour. Technol. 2015, 197, 356-362. [CrossRef] [PubMed]

45. Shen, S.; Wang, L.; Tzou, M.; Yan, Y.; Kuan, W. Removal of hexavalent Cr by coconut coir and derived chars-the effect of surface functionality. Bioresour. Technol. 2012, 104, 165-172. [CrossRef] [PubMed]

46. Sheng, Z.H.; Shao, L.; Chen, J.J.; Bao, W.J.; Wang, F.B.; Xia, X.H. Catalyst-Free Synthesis of Nitrogen-Doped Graphene via Thermal Annealing Graphite Oxide with Melamine and Its Excellent Electrocatalysis. ACS Nano 2011, 5, 4350-4358. [CrossRef] 


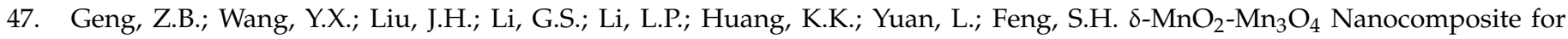
pHotochemical Water Oxidation: Active Structure Stabilized in the Interface. ACS Appl. Mater. Interfaces 2016, 8, $27825-27831$. [CrossRef] [PubMed]

48. Wang, Q.; Wang, B.; Lee, X.; Lehmann, J.; Gao, B. Sorption and desorption of $\mathrm{Pb}(\mathrm{II})$ to biochar as affected by oxidation and $\mathrm{pH}$. Sci. Total Environ. 2018, 634, 188-194. [CrossRef]

49. Park, M.; Han, H.; Chu, H.; Her, N.; Heo, J.; Yoon, Y. Influence of solution pH, ionicstrength, and humic acid on cadmium adsorption onto activated biochar: Experiment and modeling. J. Ind. Eng. Chem. 2017, 48, 186-193. [CrossRef]

50. Jiang, X.; Rui, H.; Guangcai, C. Micro-nano-engineered nitrogenous bone biochar developed with a ball-milling technique for high-efficiency removal of aquatic $\mathrm{Cd}(\mathrm{II}), \mathrm{Cu}(\mathrm{II})$ and $\mathrm{Pb}(\mathrm{II})$. J. Hazard. Mater. 2019. [CrossRef]

51. Wan, L.; Qiu, L.; Tang, G.; Chen, Y.; Li, Y.; He, F. Ultrafast sequestration of cadmium and lead from water by manganese oxide supported on a macro-mesoporous biochar. Chem. Eng. J. 2020. [CrossRef]

52. Lee, J.; Park, H.; Ahn, T.; Chung, W. Comparison of heavy metal adsorption by peat moss and peat moss-derived biochar produced under different carbonization conditions. Water Air Soil Pollut. 2015, 226, 9-20. [CrossRef]

53. James, B.; Laura, R.; Robert, D. Ion exchange removal of $\mathrm{Cu}(\mathrm{II}), \mathrm{Fe}(\mathrm{II}), \mathrm{Pb}(\mathrm{II})$ and $\mathrm{Zn}(\mathrm{II})$ from acid extracted sewage sludge-resin screening in weak acid media. Water Res. 2019, 158, 257-267.

54. Luo, C.; Wei, R.; Guo, D.; Zhang, S.; Yan, S. Adsorption behavior of $\mathrm{MnO}_{2}$ functionalized multi-walled carbon nanotubes for the removal of cadmium from aqueous solutions. Chem. Eng. J. 2013, 225, 406-415. [CrossRef]

55. Zhang, Y.; Duan, M. Chemical precipitation of heavy metals from wastewater by using the synthetical magnesium hydroxy carbonate. Water Sci. Technol. 2020, 81, 1130-1136. [CrossRef]

56. Wang, R.Z.; Huang, D.L.; Liu, Y.G.; Zhang, C.; Lai, C.; Zeng, G.M.; Cheng, M.; Gong, X.M.; Wan, J.; Luo, H. Investigating the adsorption behavior and the relative distribution of $\mathrm{Cd}^{(2+)}$ sorption mechanisms on biochars by different feedstock. Bioresour. Technol. 2018, 261, 265-271. [CrossRef]

57. Irene, L.; Zhang, H. EDTA-Enhanced Washing for Remediation of Pb and or Zn Contaminated Soils. J. Environ. Eng. 2006, 132, 1282-1288.

58. Deng, J.; Liu, Y.; Liu, S.; Zeng, G.; Tan, X.; Huang, B.; Tang, X.; Wang, S.; Hua, Q.; Yan, Z. Competitive adsorption of Pb(II), $\mathrm{Cd}(\mathrm{II})$ and $\mathrm{Cu}(\mathrm{II})$ onto chitosan-pyromellitic dianhydride modified biochar. J. Colloid Interface Sci. 2017, 506, 355-364. [CrossRef] [PubMed]

59. Wang, Z.; Ge, H. Adsorption of chromium(VI) from aqueous solution using a novel chitosan biguanidine. J. Dispers. Sci. Technol. 2015, 36, 1106-1114. [CrossRef]

60. Hong, W.; Zhuang, Z.T.; Ling, J.; Wen, W.L.; Zheng, G.W.; Shi, Y.L.; Jing, C.; Wei, W. Highly efficient adsorption of Cr(VI) from aqueous solution by $\mathrm{Fe}^{3+}$ impregnated biochar. J. Dispers. Sci. Technol. 2017, 38, 815-825.

61. Iskandar, N.; Zainudin, N.; Tan, S. Tolerance and biosorption of copper $(\mathrm{Cu})$ and $(\mathrm{Pb})$ by filamentous fungi ioslated from a freshwater ceosytem. J. Environ. Sci. (Engl. Ed.) 2011, 23, 824-830. [CrossRef]

62. Liang, J.; Li, X.; Yu, Z.; Zeng, G.; Lou, Y.; Jiang, L.; Yang, Z.; Qian, Y.; Wu, H. Amorphous MnO $_{2}$ modified biochar derived from aerobically composted swine manure for adsorption of $\mathrm{Pb}(\mathrm{II})$ and $\mathrm{Cd}(\mathrm{II})$. ACS Sustain. Chem. Eng. 2017, 5, 5049-5058. [CrossRef]

63. Chen, S.; Yue, Q.; Gao, B.; Xu, X. Equilibrium and kinetic adsorption study of the adsorptive removal of $\mathrm{Cr}(\mathrm{VI}) \mathrm{using}$ modifed wheat residue. J. Colloid Interface Sci. 2010, 349, 256-264. [CrossRef] [PubMed]

64. Acharya, J.; Sahu, J.; Mohanty, C.; Meikap, B. Removal of ledf(II) from wastewater activated carbon developed from Tamrind wood by zinc chloride activation. Chem. Eng. J. 2009, 149, 249-262. [CrossRef]

65. You, D.; Min, X.; Liu, L.; Ren, Z.; Xiao, X.; Pavlostathis, S.G.; Luo, J.M.; Luo, X.B. New insight on the adsorption capacity of metallogels for antimonite and antimonate removal: From experimental to theoretical study. J. Hazard. Mater. 2018, 346, 218-225. [CrossRef]

66. Devi, P.; Saroha, A. Risk analysis of pyrolyzed biochar made from paper mill effluent treatment plant sludge for bioavailability and ecotoxicity of heavy metals. Bioresour. Technol. 2014, 162, 308-315. [CrossRef]

67. He, Y.D.; Zhai, Y.B.; Li, C.T.; Yang, F.; Chen, L.; Fan, X.P.; Peng, W.F.; Fu, Z.M. The fate of Cu, Zn, Pb and Cd during the pyrolysis of sewage sludge at different temperatures. Environ. Technol. 2010, 31, 567-574. [CrossRef] [PubMed]

68. Yang, B.; Gong, Q.; Zhao, L.; Sun, H.; Ren, N.; Qin, J.; Xu, J.; Yang, H. Preconcentration and determination of lead and cadmium in water samples with a $\mathrm{MnO}_{2}$ coated carbon nanotubes by using ETAAS. Desalination 2011, 278, 65-69. [CrossRef]

69. Hakanson, L. An ecological risk index for aquatic pollution control: A sedimentological approach. Water Res. 1980, 14, 975-1001. [CrossRef] 